\title{
THE INITIAL CRITICAL AND \\ ZERO POWER TESTING \\ OF THE HWCTR
}

T. C. Gorrell

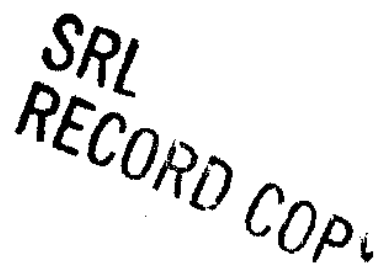

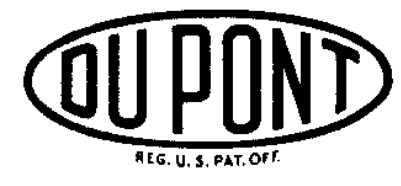

Savannah River Laboratory

Aiken, South Carolina 


\section{LEGAL NOTICE}

This report was prepared as an account of Government sponsored work. Neither the United States, nor the Commission, nor any person acting on behalf of the Commission:

A. Makes any warranty or representation, expressed or implied, with respect to the accuracy, completeness, or usefulness of the information contained in this report, or that the use of any information, apparatus, method, or process disclosed in this report may not infringe privately owned rights; or

B. Assumes any liabilities with respect to the use of, or for damages resulting from the use of any information, apparatus, method, or process disclosed in this report.

As used in the above, "person acting on behalf of the Commission" includes any employee or contractor of the Commission, or employee of such contractor, to the extent that such employee or contractor of the Commission, or employee of such contractor prepares, disseminates, or provides access to, any information pursuant to his employment or contract with the Commission, or his employment with such contractor.

Printed in USA. Price $\$ 2.00$

Avaliable from the Clearinghouse for Federal Sclentific and Technical Information, National Bureau of Standards,

U.S. Department of Commerce; Springfield, Virginia 
Reactor Technology

(TID-4500, 45th Ed.)

\section{THE INITIAL CRITICAL AND ZERO POWER} TESTING OF THE HWCTR

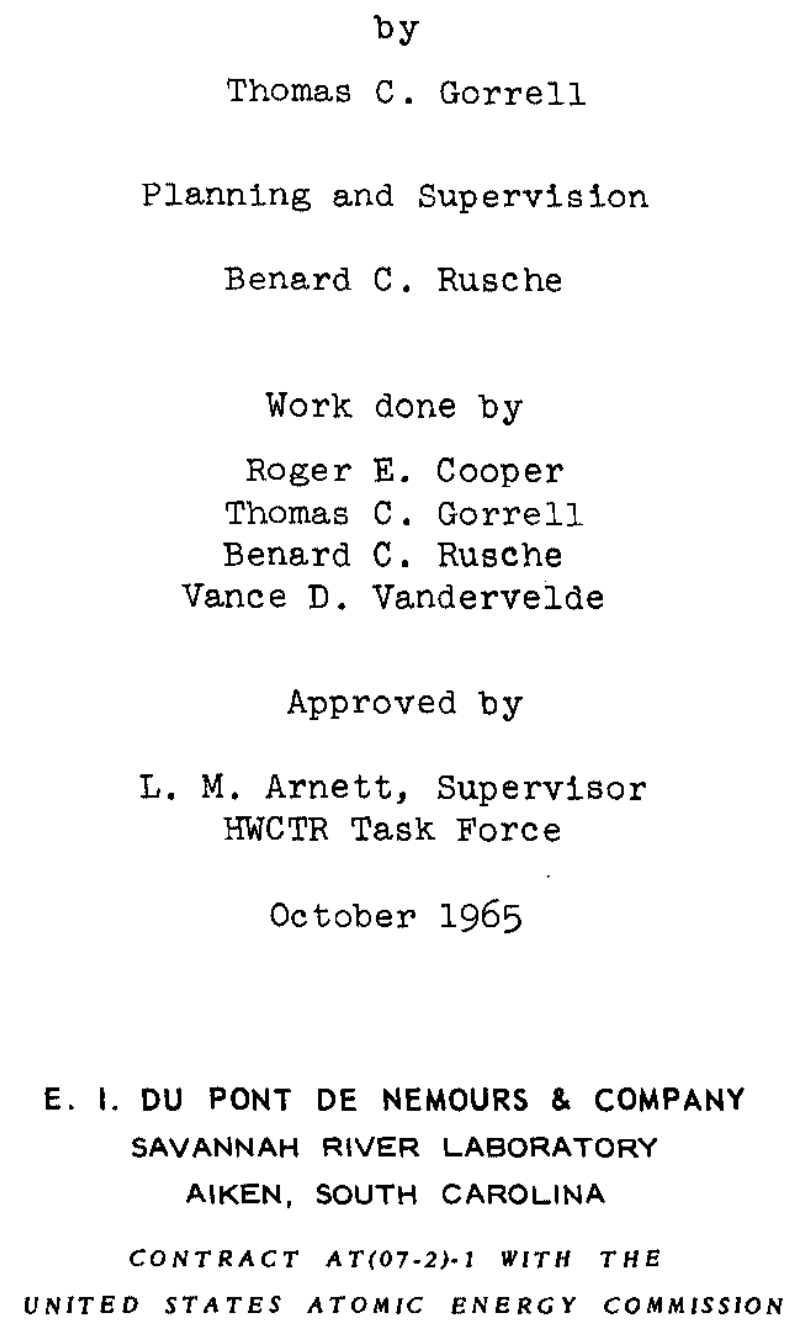




\begin{abstract}
The Initial lattice of the Heavy Water Components Test Reactor (HWCTR) was assembled and was made critical without incident. The reactivity worth of the control system and the reactivity effects of temperature were measured in a serles of zero power tests. The axial and radial flux distributions were measured for several control rod complements. The results of the complete set of tests demonstrated that the operating behavior of the reactor could be predicted with consistency, and provided the basis for proceeding to full power, nuclear operation.
\end{abstract}




\section{CONTENTS}

Page

List of Tables and Figures............... IV

Introduction . . . . . . . . . . . . . . . 1

Summary . . . . . . . . . . . . . . . . . 1

Discussion...................... 2

Fac1l1ty Description ............... . 2

Material Content of Core Components . . . . . . . . 7

Driver Fuel and Target Elements . . . . . . . 7

Control Rods and Safety Rods . . . . . . . 8

Inttial Critical . . . . . . . . . . . 9

Loading the Reactor Core . . . . . . . . 9

Attaining Criticality . . . . . . . . . 10

Reactivity Worth of Control System . . . . . . 16

Ring Control Rods . . . . . . . . . . 16

Safety Rods . . . . . . . . . . . . 21

Center Cluster Control Rods.......... 25

Temperature Coefflcient of Reactivity . . . . . . 25

Flux D1stributions . . . . . . . . . . 25

Radial flux . . . . . . . . . . . 27

Axlal flux .............. 34

Bibllography ................. 45 


\section{LIST OF TABLES AND FIGURES}

Table Page

$\begin{array}{rlr}\text { I } & { }^{235} \mathrm{U} \text { Content of HWCTR Driver Elements . . . . } & 8 \\ \text { II } & \text { Nuclear Instruments . . . . . . . . . . . . . . . . . . . } & 9 \\ \text { III } & \text { Rod Worths at } 240^{\circ} \mathrm{C} \text { Moderator Temperature . }\end{array}$

Figure

I HWCTR Containment Building . . . . . . . . 3

2 Reactor Vessel and Component Arrangement . . . 4

3 Lattice Arrangement . . . . . . . . . . . 5

4 Driver and Test Fuel Assemblies . . . . . . . 6

5 Count Rate Ratio vs $\mathrm{D}_{2} \mathrm{O}$ Level in Reactor Core . . 11

6 Internal $\mathrm{BF}_{3}$ Chamber Current vs $\mathrm{D}_{2} \mathrm{O}$

Level in Reactor Core........... 12

7 External Fission Counter Count Rate vs $\mathrm{D}_{2} \mathrm{O}$

Level in Reactor Core ............ 13

8 External $\mathrm{BF}_{3}$ Count Rate vs $\mathrm{D}_{2} \mathrm{O}$ Level in

9 Axial Position of Ring Control Rods

vs Moderator Temperature . . . . . . . . . 17

10 Axial Position of 10 Ring Control

Rods vs Axlal Position of Rods 1 and 7 . . . . 18

11 Excess Reactivity vs Flux Doubling Time . . . . 19

12 Incremental Rod Worth vs Position of Rod No. 1 . 20

13 Reactivity Worth of 12 Ring Control

Rods vs Moderator Temperature .. . . . . . 22

14 Fractional Rod Worth va Axial Position

of Ring Rods . . . . . . . . . . . . . 24

15 Temperature Coefficlent of Reactivity

vs Moderator Temperature . . . . . . . 26

16-24 Measured Radial Flux Distribution....28-33,36-38

25 Radial Computational Model . . . . . . 39

26 Axial Computational Model ............ 40

27 Calculated Radial Flux Distribution....... 41

28 Calculated Radial Flux Distribution ....... 42

29 Measured and Calculated Axial Flux Profiles. . . 43

30 Measured and Calculated Axial Flux Proflles . . . 44 
THE INITIAL CRITICAL AND ZERO POWER

TESTING OF THE HWCTR

\section{INTRODUCTION}

The Heavy Water Components Test Reactor (HWCTR) is a high temperature, pressure vessel reactor, cooled and moderated with $D_{2} O$. It was designed and constructed speciflcally to test candidate power reactor fuel elements at operating conditions and exposures similar to those expected in a full-sized $D_{2} O$ power reactor. The fuel development program was part of the Du Pont program to advance the technology of $\mathrm{D}_{2} \mathrm{O}$ power reactors. Operation of the HWCTR was terminated on December I, 1964, following a decision by the AEC to redirect the heavy water program toward organic cooled reactors. The HWCTR facility has been placed in a standby condition.

Construction of the HWCTR was begun in 1958 and completed early in 1962. A serles of zero power tests was conducted to attain the inftial critical and to measure basic lattice parameters before attaining full power conditions. Parameters of special interest that were investigated included the excess lattice reactivity, the reactivity margin of control, the maximum possible rate of reactivity addition, the radial and axial flux distributions, and the reactivity effects of temperature. The results of this study are presented in this report.

\section{SUMMARY}

The initial core of the HWCTR driver fuel (zirconium-enriched uranlum) was assembled and was made critical under carefully controlled conditions on March 3, 1962. No fuel was present in the test lattice positions. Following the complete withdrawal of the fast-acting safety rods, the reactivity added by the withdrawal of control rods to attain criticality was $0.08 \mathrm{~K}$. After thorough appralsal, natural uranium test fuel was charged, the complete initial core was made critical, and zero power measurements were made with this loading.

The worth of the control rod system measured by the p1le-perlod technique was:

\begin{tabular}{|c|c|c|c|}
\hline Lattice & $\begin{array}{c}\text { Moderator } \\
\text { Temperature, }{ }^{\circ} \mathrm{C} \\
\end{array}$ & $\begin{array}{l}\text { Worth of } \\
\text { One Rod, K } \\
\end{array}$ & $\begin{array}{l}\text { Worth of } \\
\text { I2 Rods, } \mathrm{K}\end{array}$ \\
\hline Driver fuel only & $\begin{array}{r}20 \\
240\end{array}$ & $\begin{array}{l}0.020 \\
0.023\end{array}$ & $\begin{array}{l}0.234 \\
0.276\end{array}$ \\
\hline Driver and test fuel & $\begin{array}{r}20 \\
240\end{array}$ & $\begin{array}{l}0.017 \\
0.020\end{array}$ & $\begin{array}{l}0.200 \\
0.240\end{array}$ \\
\hline
\end{tabular}


The worth of the $\mathrm{s} 1 \mathrm{x}$ safety rods was $0.09 \mathrm{~K}$ in the driver and test fuel lattice at $20^{\circ} \mathrm{C}$.

The maximum moderator temperature $\left(250^{\circ} \mathrm{C}\right)$ at which the driver and test lattice could be operated was Imposed by the worth of the safety rod system, which, in accordance with AEC Technical specifications, must exceed by $0.01 \mathrm{~K}$ the reactivity gained in reducing the moderator temperature from the operating value to $20^{\circ} \mathrm{C}$.

The radial and axial flux distributions were measured in several lattice arrangements. The results were used to develop both a radial and an axial computational model. During power operation, the axial flux distributions must be obtalned solely by computations, in lieu of in-core instrumentation.

The maximum rate at which reactivity could be introduced by the withdrawal of a single control rod was $2.6 \times 10^{-4} \mathrm{~K} / \mathrm{sec}$ at $20^{\circ} \mathrm{C}$ and $3.1 \times 10^{-4} \mathrm{~K} / \mathrm{sec}$ at $240^{\circ} \mathrm{C}$.

\section{DISCUSSION}

\section{FACILITY DESCRIPTION}

A detailed description of the HWCTR faclitty is given in reference 1. Only a brief description of the reactor and 1ts associated equipment will be given here.

The reactor and princlpal auxiliary equipment are housed in a bullding designed to confine steam and radioactivity that might be released by accldental rupture of the reactor system. The containment bullding is constructed of carbon steel and stressed, reinforced concrete. The building is 70 feet in diameter and 125 feet high, with half of the bullding above grade. The containment building is shown in Figure 1 .

An isometric drawing of the reactor vessel is shown in Figure 2. The vessel is approximately 30 feet high. The reactor core is in the lower third of the vessel. Core components are charged or removed through the top of the vessel. Control rods and safety rods are driven by motors and gear assemblies mounted above the reactor head. Primary $\mathrm{D}_{2} \mathrm{O}$ coolant, circulated through two 1dentical systems, enters the vessel above the fuel, passes down through the fuel coolant annuli, and enters the bulk moderator region. The $D_{2} O$ leaves the vessel through two nozzles near the top of the fuel, and passes through two steam generators before returning to the reactor. 


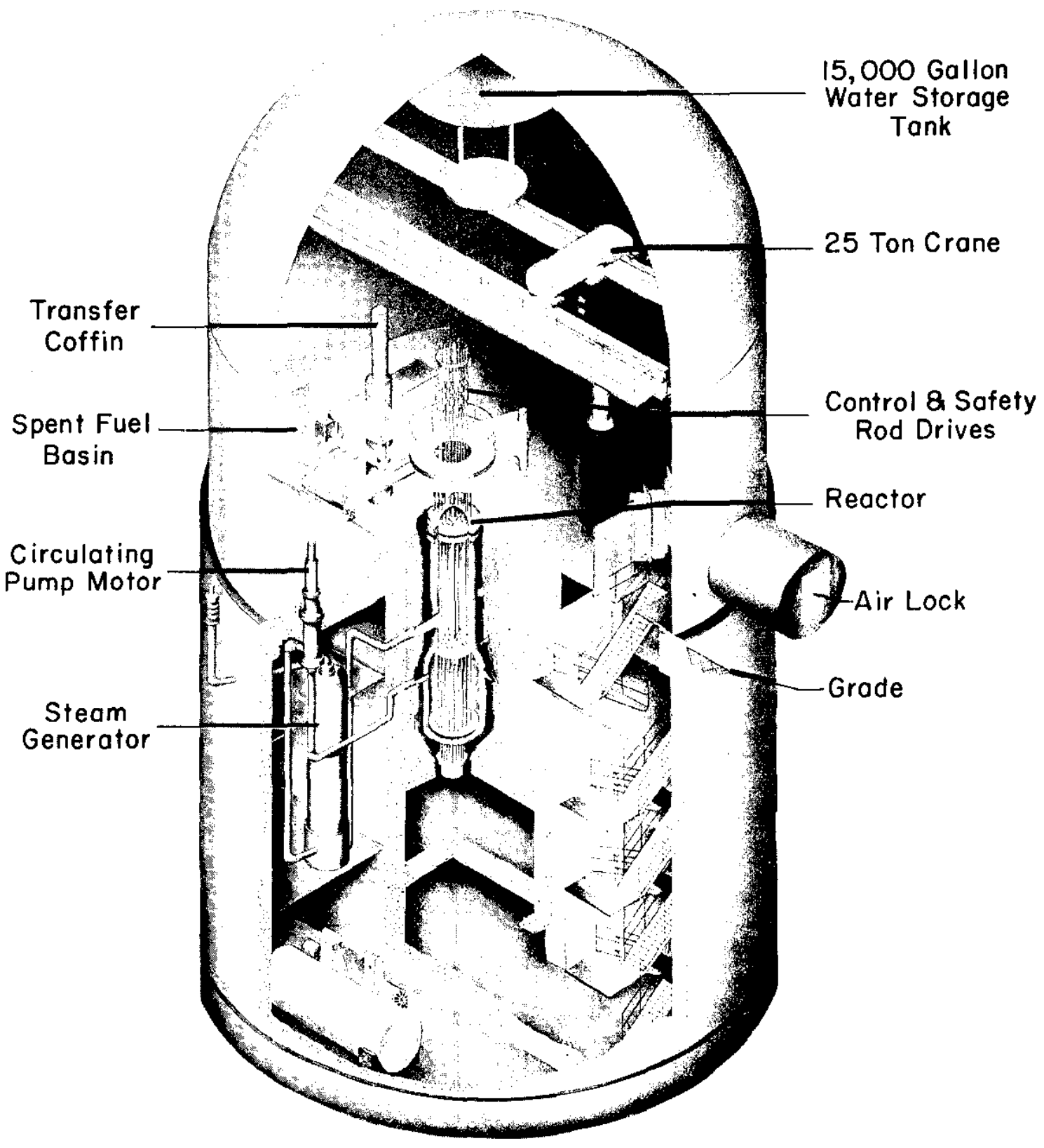

FIG. I HWCTR CONTAINMENT BUILDING 


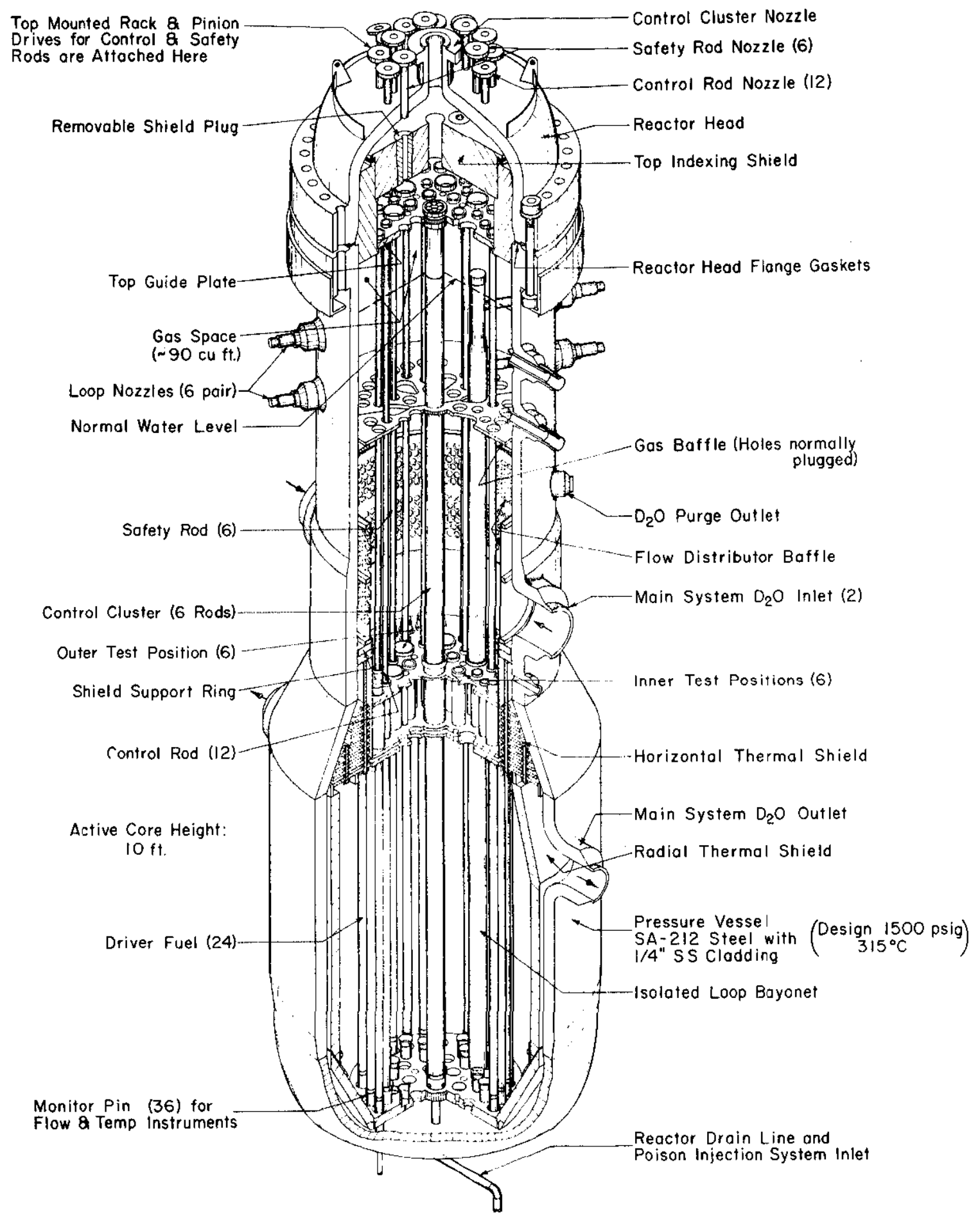

FIG. 2 REACTOR VESSEL AND COMPONENTS ARRANGEMENT 
A cross section of the reactor core 1s shown in Figure 3. The driver fuel elements, in slx groups of four elements each, surround the test region. The driver fuel provides the necessary lattice reactivity for operation at full power and temperature. There are 12 test fuel positions inside the driver ring, arranged on a seveninch triangular spacing. Isolated pressure tubes occupy two of the test positions, and serve to separate their fuel coolant from the main system moderator. Each pressure tube is connected to a separate flow loop having its own pumps and heat removal system. The isolated pressure tubes contalned $\mathrm{D}_{2} \mathrm{O}$ only during the low power tests.

Twelve control rods and six safety rods are arranged in concentric rings inside the driver fuel. A cluster of $s 1 x$ control rods occupies the core center. The control and safety rods are tubes of boronated stainless steel having an outside diameter of 1.25 inches and an inside diameter of 1.00 inch. The natural boron content is $1.0 \mathrm{wt} \%$. The control rods are driven in or out at a maximum speed of 2.5 feet per minute. The safety rods are driven out at a speed of 2.5 feet per minute, and can be rapidly inserted from their full out position to $90 \%$ Insertion in less than two seconds, following a scram signal.

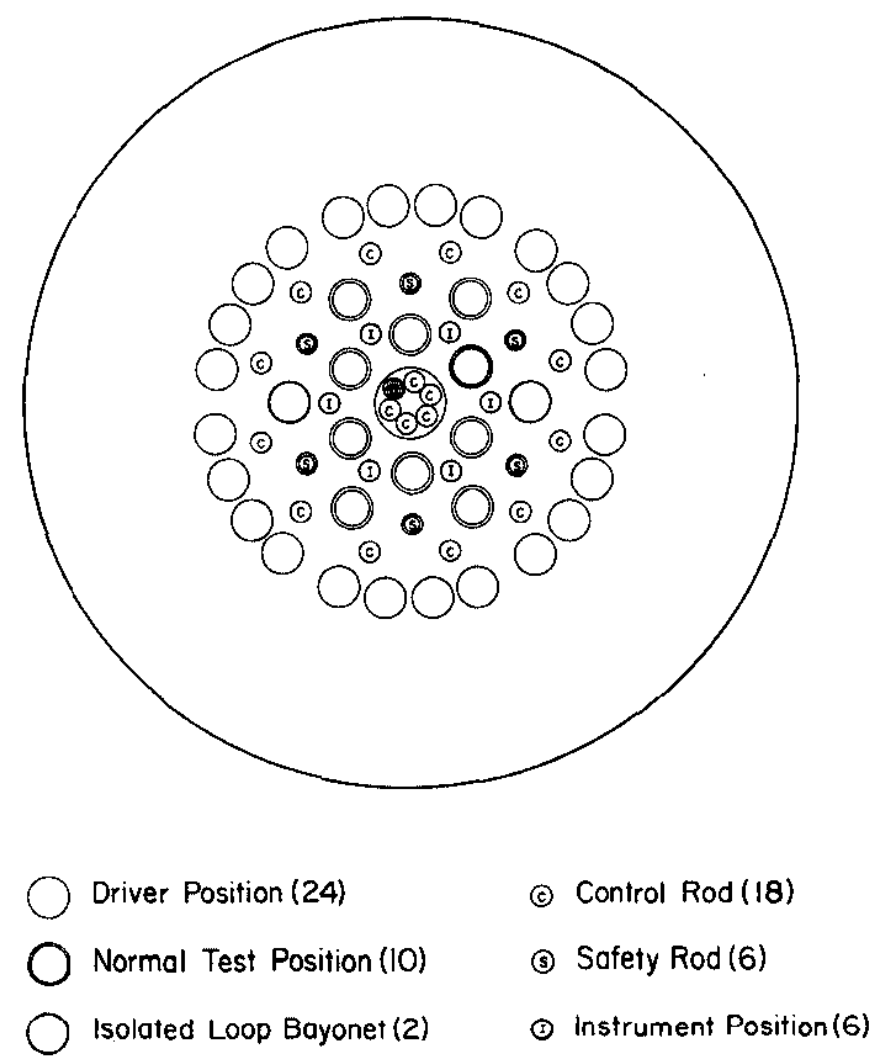

FIG. 3 LATTICE ARRANGEMENT 
The inftial driver and typical test fuel assemblies are shown in Figure 4. The driver fuel tube is Zircaloy clad and contains a ${ }^{235} \mathrm{U}$ loading of $108 \mathrm{~g} / \mathrm{ft}$, alloyed with zirconium. The fuel was fabricated by Nuclear Metals, Inc. The target elements, or burnable polson components, consist of a column of foot-long pairs of boronated stainless steel plates arranged in the shape of a cross.

\section{DRIVER ASSEMBLY}

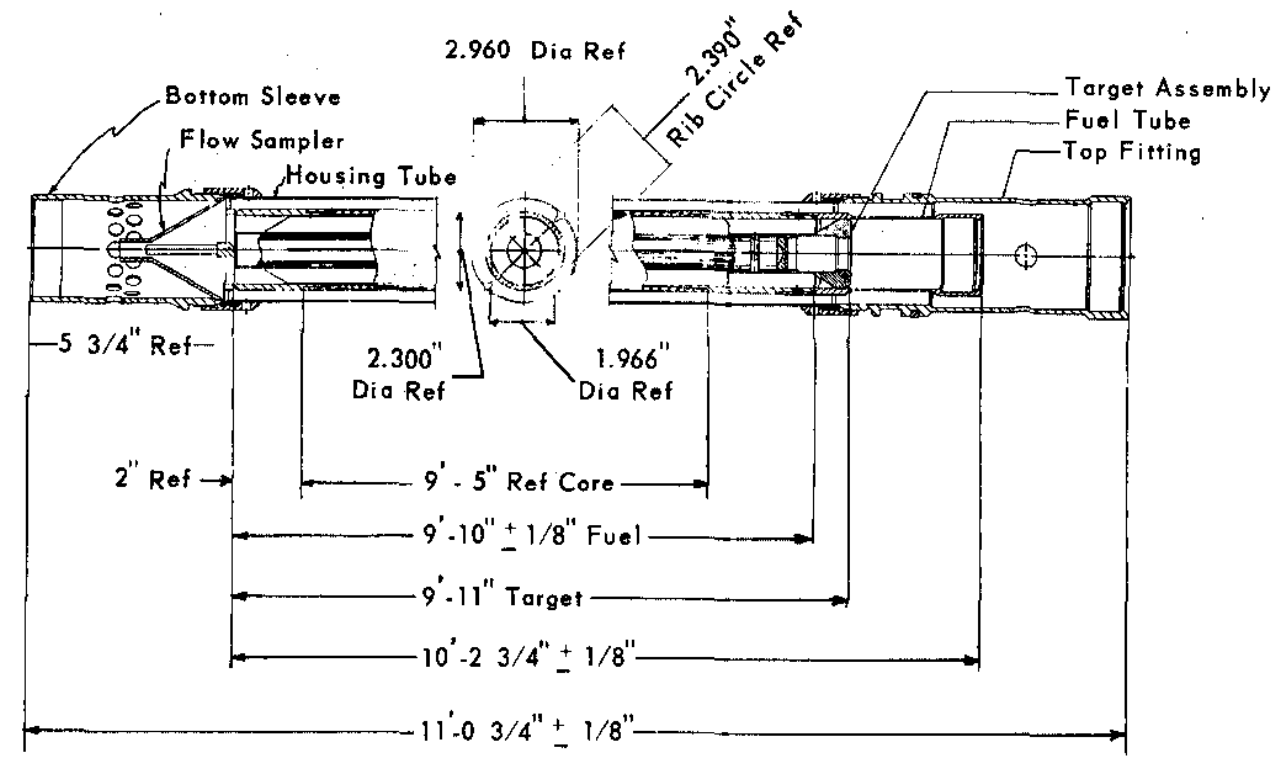

FUEL ASSEMBLY

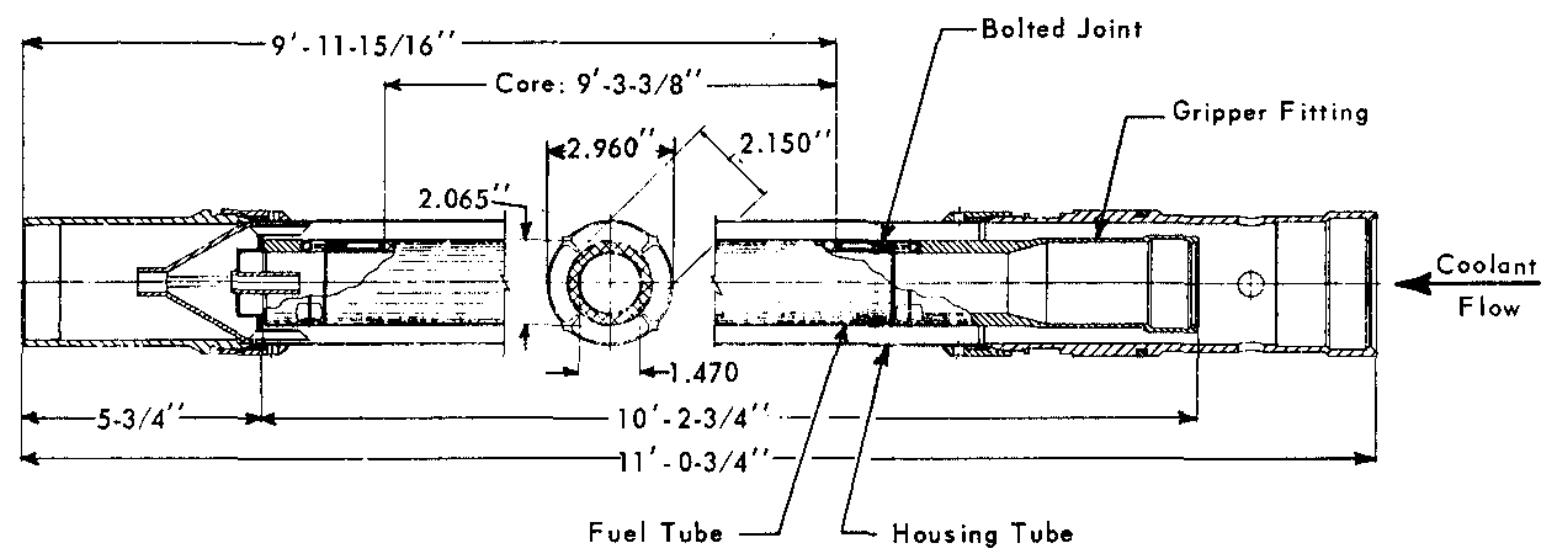

FIG. 4 DRIVER AND TEST FUEL ASSEMBLIES

The test elements used during part of the low power tests were natural uranium tubes clad in Zircaloy. These elements were not of power operation quality, but provided a satisfactory test region lattice for the zero power tests. 
Normal operating conditions for the HWCTR are achieved at a reactor power of approximately $50 \mathrm{MW}$ and a moderator temperature of $250^{\circ} \mathrm{C}$. Pressurization is provided by a helium gas system, including a small volume of helium in the top of the vessel. Energy is removed from the system by boiling $\mathrm{H}_{2} \mathrm{O}$ on the shell side of two vertical $\mathrm{U}$-tube steam generators. The steam is vented to the atmosphere.

During the tests described in this report, reactor power did not exceed $10 \mathrm{KW}$. Some tests were conducted at elevated temperature. In those instances, energy was added to the system by operating the main system pumps at full $\mathrm{D}_{2} \mathrm{O}$ flow, with no coolant $\mathrm{H}_{2} \mathrm{O}$ in the steam generators.

\section{MATERIAL CONTENT OF CORE COMPONENTS}

An important part of the prestartup preparations consisted of determining the materlal content of core components such as fuel, target elements, control rods, and safety rods. A summary of these analyses is given below.

\section{Driver Fuel and Target Elements}

The ${ }^{235} \mathrm{U}$ content of the driver fuel was measured by the vendor, Nuclear Metals, Inc. (NMI), and by SRP personnel operating the Nuclear Test Gage (NTG). (2) The results of these measurements are given in Table I for both the inftial driver charge $(M-I)$ and the second driver charge $(\mathrm{M}-2)$. Only the $\mathrm{M}-1$ drivers were used in the physics tests described in this report.

No direct comparison can be made between the total amount of ${ }^{235} \mathrm{U}$ in any element and the specific loading of the element, in $\mathrm{g} / \mathrm{ft}$. A tube that is above average in total ${ }^{235} \mathrm{U}$ content, for example, may be below average in the specific loading. These differences can be attributed to differences in fuel core length between tubes and to errors inherent in each method of measurement. The total spread in $23{ }^{2} \mathrm{U}$ content was not so large as to introduce a significant reactivity uncertainty or to create a power-limiting "hot spot".

The boron content of the target blades was determined from neutron transmission measurements. The average natural boron content of the 51.0 target blades was 0.34 wt $\%$, corresponding to $0.61 \mathrm{~g} / \mathrm{ft}$ of natural boron. Good agreement was obtained between the results of chemical analyses and neutron transmission measurements made on a selected few samples. The target blades used to make up an assembly for a given driver element were taken randomly from the group. Each driver element contained 20 target blades, so that differences in reactivity worth among the assembled target elements were minor. 
TABLE I

$235 \mathrm{U}$ Content of HWCTR Driver Elements

\begin{tabular}{|c|c|c|c|c|c|c|c|c|}
\hline \multirow[b]{3}{*}{$\begin{array}{r}\text { Lattice } \\
\text { Position } \\
\text { No. } \\
\end{array}$} & \multicolumn{4}{|c|}{ M-1 Set } & \multicolumn{4}{|c|}{ M-2 Set } \\
\hline & \multirow[b]{2}{*}{$\begin{array}{l}\text { Tube } \\
\text { No. }\end{array}$} & \multirow[b]{2}{*}{$\begin{array}{l}\text { NMI } \\
235 \mathrm{U} \\
\mathrm{g}\end{array}$} & \multicolumn{2}{|c|}{ NTG Data } & \multirow[b]{2}{*}{$\begin{array}{l}\text { Tube } \\
\text { No. }\end{array}$} & \multirow[b]{2}{*}{ 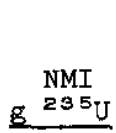 } & \multicolumn{2}{|c|}{ NTG Data } \\
\hline & & & $\begin{array}{c}\text { Avg } 235 \mathrm{U}, \\
\mathrm{g} / \mathrm{ft}\end{array}$ & $\begin{array}{r}\text { Max Variation } \\
\text { along Tube, * } \\
\mathrm{g} / \mathrm{ft}\end{array}$ & & & $\begin{array}{l}\text { Avg } 235 \mathrm{U}, \\
\mathrm{g} / \mathrm{ft}\end{array}$ & $\begin{array}{l}\text { Max Varlation } \\
\text { along Tube, } \\
\mathrm{g} / \mathrm{ft} \\
\end{array}$ \\
\hline 1 & 8 & 941 & 109.5 & 1.4 & 29 & 966 & 210.9 & 1.8 \\
\hline 2 & 20 & 956 & 108.7 & 1.2 & 41 & 948 & 107.6 & 1.2 \\
\hline 3 & 15 & 957 & 109.0 & 1.6 & 7 & 949 & 108.5 & 2.3 \\
\hline 4 & 42 & 958 & 108.7 & 1.2 & 6 & 947 & 109.1 & 1.8 \\
\hline 5 & 44 & 955 & 108.6 & 1.2 & 13 & 967 & 110.4 & 2.6 \\
\hline 6 & 40 & 952 & 108.0 & 1.2 & 37 & 953 & 107.7 & 1.5 \\
\hline 7 & 46 & 972 & 109.2 & 1.3 & 3 & 943 & 108.9 & 1.1 \\
\hline 8 & 34 & 955 & 108.0 & 0.9 & 52 & 957 & 109.1 & 2.5 \\
\hline 9 & 36 & 947 & 108.2 & 1.4 & 43 & 960 & 110.0 & 1.5 \\
\hline 10 & 35 & 939 & 108.0 & 1.1 & 38 & 949 & 108.0 & 1.0 \\
\hline 11 & 48 & 954 & 107.7 & 1.0 & 25 & 954 & 108.2 & 2.1 \\
\hline 12 & 31 & 953 & 108.1 & 1.7 & 26 & 966 & 109.6 & 2.4 \\
\hline 13 & 33 & 964 & 108.9 & 1.7 & 30 & 966 & 110.9 & 1.6 \\
\hline 14 & 24 & 941 & 108.6 & 1.8 & 27 & 946 & 107.7 & 1.9 \\
\hline 15 & 22 & 950 & 109.6 & 1.8 & 16 & 952 & 108.5 & 1.9 \\
\hline 16 & 10 & 954 & 109.0 & 1.7 & 12 & 956 & 109.5 & 1.8 \\
\hline 17 & 47 & 952 & 108.2 & 1.4 & 4 & 947 & 110.2 & 1.5 \\
\hline 18 & 53 & 950 & 108.5 & 1.7 & 39 & 951 & 107.6 & 1.0 \\
\hline 19 & 55 & 955 & 108.6 & 1.3 & 18 & 948 & 108.9 & 1.9 \\
\hline 20 & 54 & 950 & 108.9 & 1.8 & 32 & 943 & 109.0 & 2.2 \\
\hline 21 & 56 & 927 & 107.5 & 1.7 & 14 & 955 & 110.0 & 1.9 \\
\hline 22 & 49 & 955 & 107.3 & 1.0 & 1 & 960 & 107.9 & 1.6 \\
\hline 23 & $5 I$ & 949 & 107.6 & 1.6 & 5 & 949 & 108.2 & 1.9 \\
\hline 24 & 50 & 946 & 108.2 & 1.2 & 17 & 963 & 109.7 & 1.7 \\
\hline & Avg & 951 & 108.4 & 1.4 & $\mathrm{Avg}$ & $\rightarrow 954$ & 109.0 & 1.8 \\
\hline
\end{tabular}

*Maximum variation is equal to the difference between the highest reading and the lowest reading along the tube.

\section{Control Rods and Safety Rods}

The average natural boron content of the control rods and safety rods was 1.06 wt $\%$ as determined from chemical analyses, and 0.97 wt $\%$ as determined by neutron transmission measurements. The reactivity worth of a HWCTR control rod was measured to be $95 \%$ the worth of a standard rod used in a HWCTR mockup experiment that was conducted in the Process Development P1le (PDP).(3) The standard rod contained 1.42 wt \% natural boron, as determined both by chemical analyses and neutron transmission measurements. 


\section{INITIAL CRITICAL}

Special attention was given to the manner in which fuel components were added to the reactor core and to the method of attaining the initial critical. Rellance was placed on information obtained from HWCTR mockup studies conducted in the PDP. (s) As described in the previous section, the material content of each fuel and control rod component was known, and was consistent with the design values set after the PDP tests. Nevertheless, the assembly of the dry core, the raising of the moderator in the shutdown core, and the attaining of the initial critical were all accompanied by continuous monitoring of changes in the neutron flux in the core. The conservative assumption was made that criticality could be achieved after any step in the startup sequence.

\section{Loading the Reactor Core}

The sequence of events to accomplish the assembly of the reactor core provided for the loading of all control rods, safety rods, and driver fuel to the dry vessel, followed by the filling of the vessel with $\mathrm{D}_{2} \mathrm{O}$. The moderator and safety rods were to be ralsed slowly together, assuring that the reactor would never approach criticality without the safety rods removed. It was anticipated that large decreases in count rate on the nuclear instruments would occur as the neutron sources and instrument chambers became covered by $\mathrm{D}_{2} \mathrm{O}$. Real changes in neutron flux multiplication would be masked by changes resulting from the geometry effects. To obtain a measure of the anticipated geometry effects, count rate data were obtained from the nuclear instruments as the $\mathrm{D}_{2} \mathrm{O}$ was drained from the reactor core containing control rods and sources, but no fuel.

\section{TABLE II}

Nuclear Instruments

\begin{tabular}{|c|c|c|c|}
\hline Instruments & $\begin{array}{r}\text { No. of } \\
\text { Systems } \\
\end{array}$ & $\begin{array}{l}\text { Probe } \\
\text { Location }\end{array}$ & Operating Range \\
\hline $\begin{array}{l}\text { Temporary } \mathrm{BF}_{3} \\
\text { (Boron-lined ion chambers) }\end{array}$ & 2 & In-core & Shutdown to $1 \mathrm{KW}$ \\
\hline $\mathrm{BF}_{3}$ & 1 & (a) & Shutdown to $5 \mathrm{KW}$ \\
\hline Fission Counter & 1 & (a) & Shutdown to $1 \mathrm{MW}$ \\
\hline High Level Monitor & 3 & (a) & 100 watts to full power \\
\hline Log-Period & 2 & (a) & 100 watts to full power \\
\hline Galvanometer & 1 & (a) & 100 watts to full power \\
\hline
\end{tabular}

(a) Sleeve external to reactor. 
The nuclear instruments used throughout the zero power test period are listed in Table II. The $\mathrm{BF}_{3}$ instruments and the fission counters were used (I) to monitor increases in multiplication during the approach to criticality, and (2) to conduct the low-flux power rise. The remalning instruments became operable at a power of approximately 100 watts and were used for all higher powers. There was sufficient overlap between the low level and high level instruments to ensure safe operation when power was raised through the instruments transition region.

Changes in count rate of each nuclear instrument versus changes in core $D_{2} \mathrm{O}$ height are shown in Figure 5 . The leakage neutron flux measured by the two external startup instruments increased by a factor of about 5000 as $\mathrm{D}_{2} \mathrm{O}$ was drained from the core. The increase in fiux at the two internal $\mathrm{BF}_{3}$ chambers was less than a factor of 10 , but occurred very abruptly as each chamber was uncovered by the $D_{2} O$.

Driver fuel elements were charged to the dry core. Small increases in count rate were observed on the two external startup systems. The external $\mathrm{BF}_{3}$ count rate increased $40 \%$ and the fission counter $18 \%$. No change in count rate was observed on the two internal $\mathrm{BF}_{3}$ instruments. No test fuel was charged at this time.

\section{Attaining Criticality}

The moderator level in the reactor core was raised in small increments, with count rate data obtained after each increment. The block valves in the two main circulation systems were locked closed to prevent the sudden addition of a large amount of $\mathrm{D}_{2} \mathrm{O}$ to the core. The six safety rods were raised in increments, with the tips of the rods maintained above the $\mathrm{D}_{2} \mathrm{O}$ level. The responses of the nuclear instruments with the increases in $D_{2} O$ level are shown in Figures 6,7 , and 8. Count rate data obtained when no fuel was present are also shown.

The removal of control rods was begun after the $D_{2} \mathrm{O}$ level was above the top shield. The six cluster rods were fully removed, resulting in the addition of about $0.025 \mathrm{~K}$. The twelve ring control rods were removed in increments in a banked configuration with count rate data obtained after each increment. A stable period was attained with all 12 ring control rods about one-third withdrawn. The power rise was terminated at a power of a few hundred watts. The initial criticality of the HWCTR was attained at 1I:31 PM on March 3, 1962. The axial position of the 12 ring control rods was 650 veeder units.*

*A fully inserted control rod has the axial position of 1000 veeder units, and a fully removed rod, zero veeder units. The total rod travel is 114 inches. 


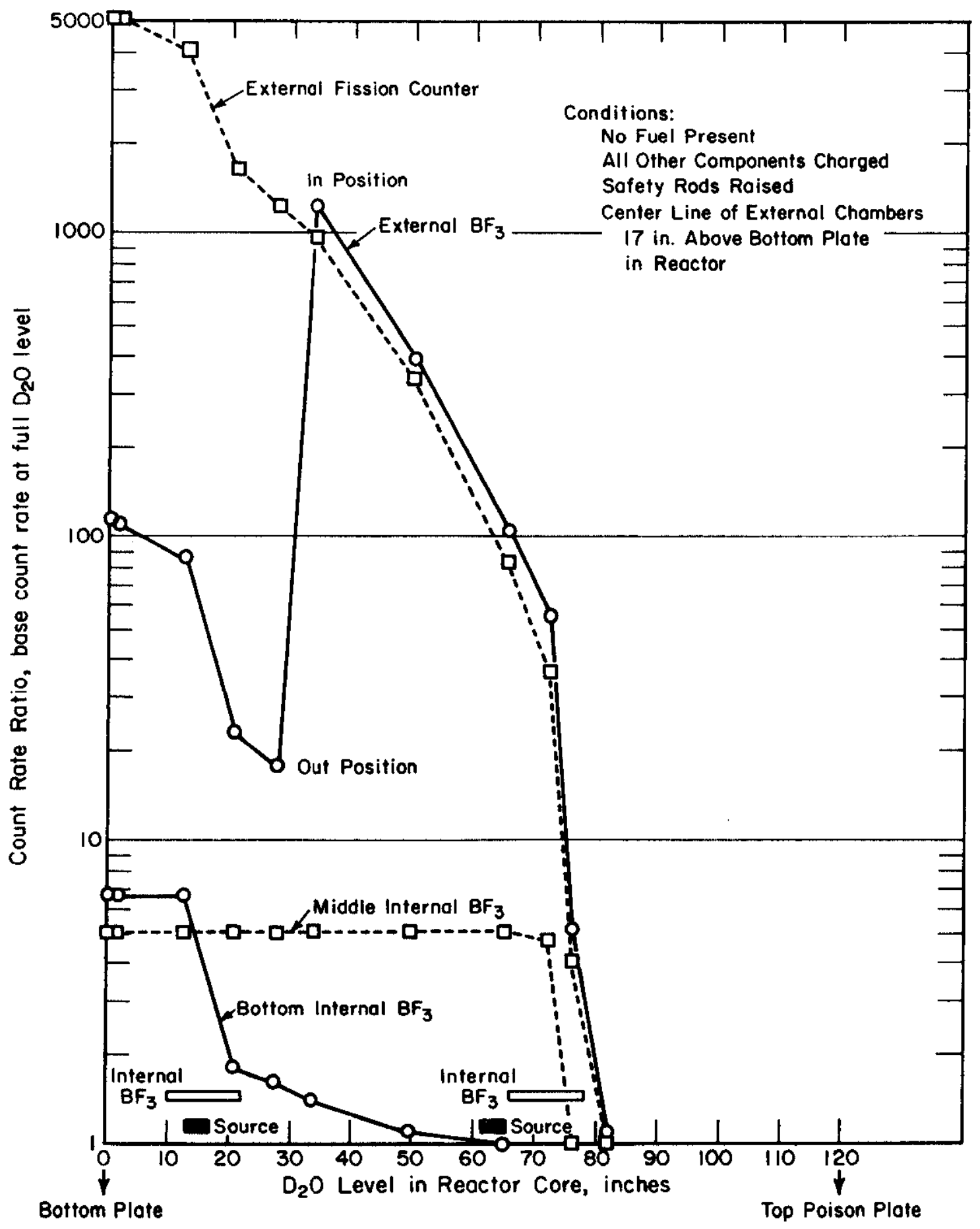

FIG. 5 COUNT RATE RATIO VS. $D_{2} O$ LEVEL IN REACTOR CORE 


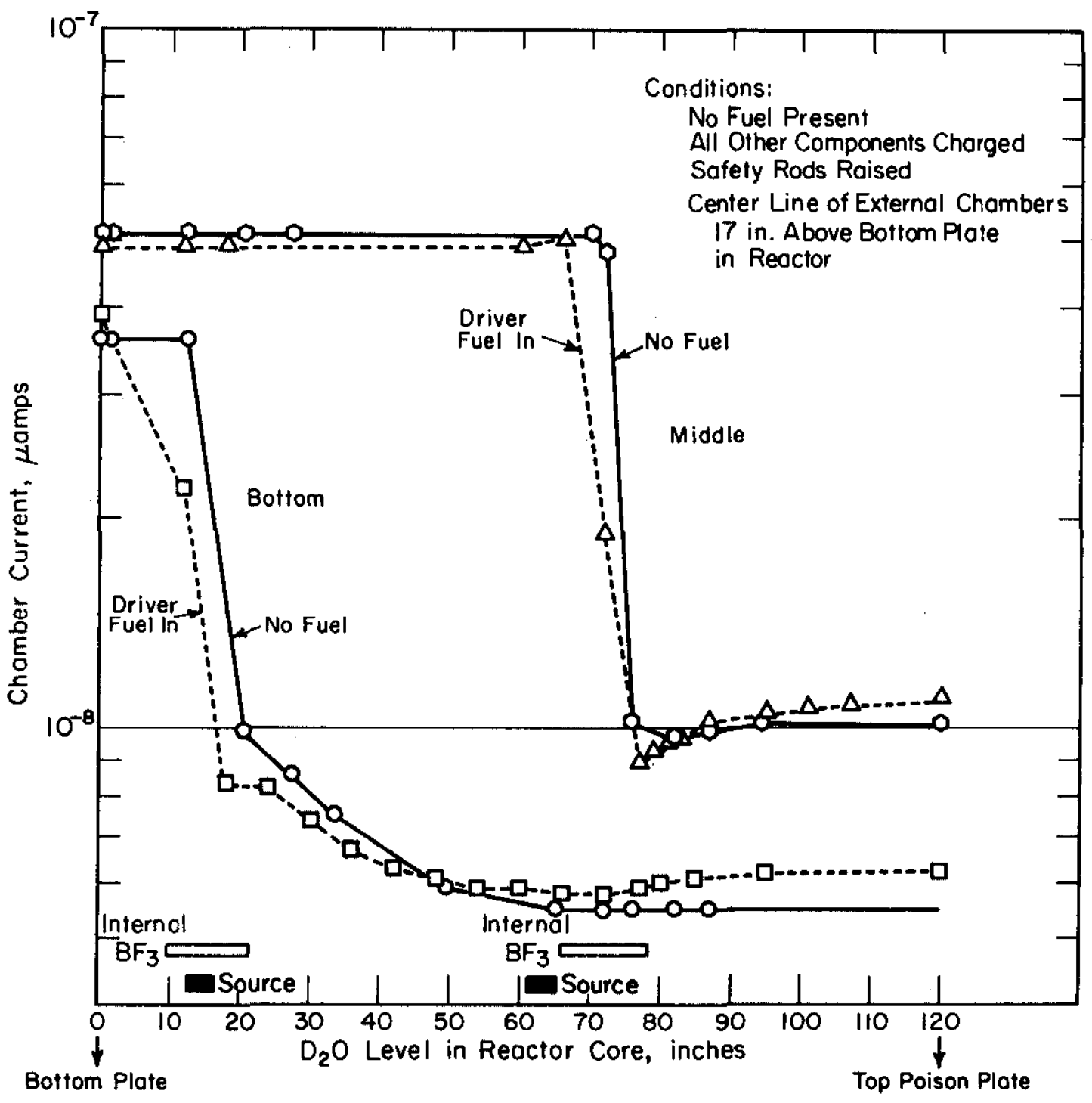

FIG. 6 INTERNAL BF 3 CHAMBER CURRENT VS. $D_{2}$ O LEVEL IN REACTOR CORE 


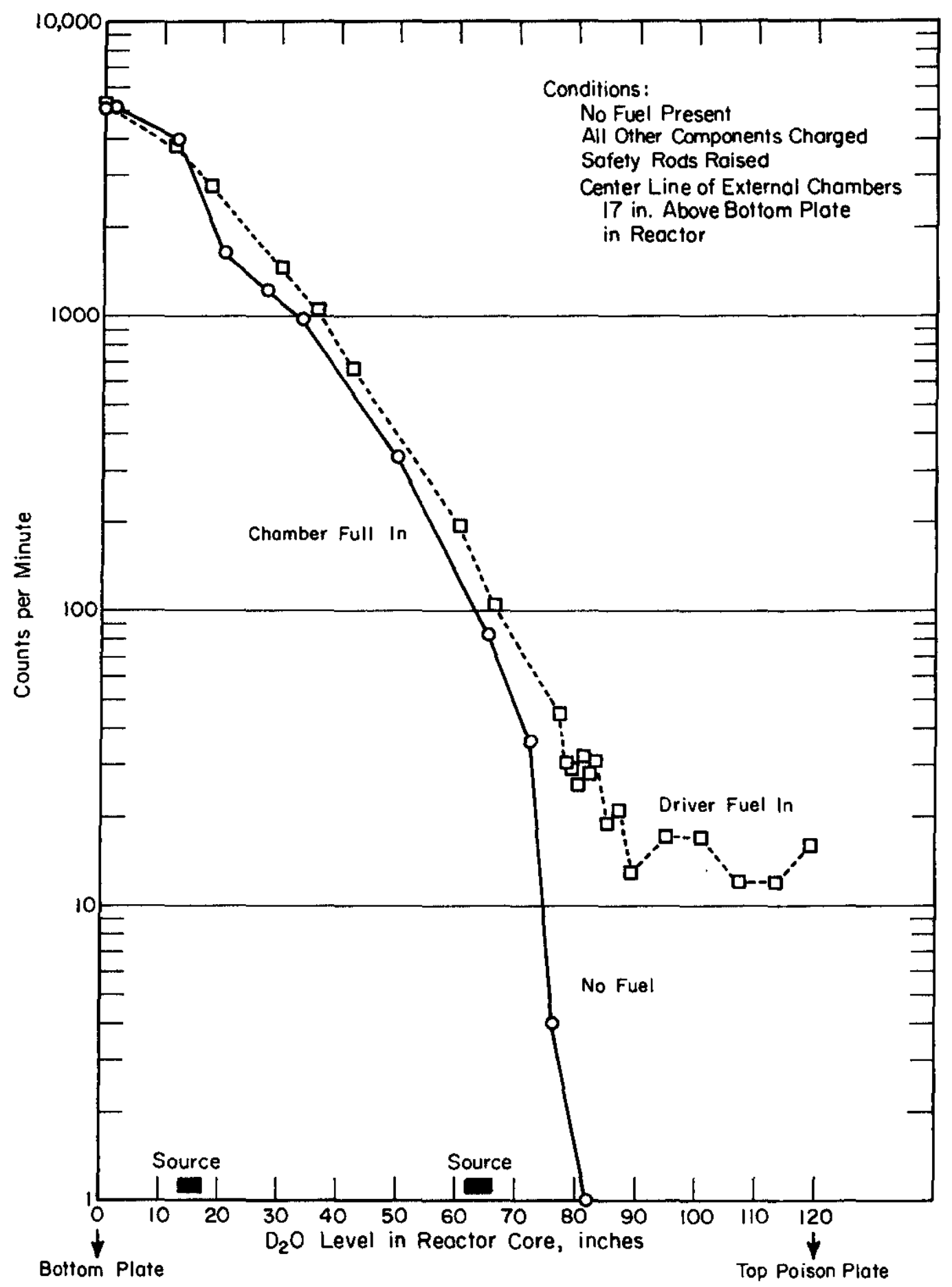

FIG. 7 EXTERNAL FISSION COUNTER COUNT RATE VS. $D_{2}$ O LEVEL IN REACTOR CORE 


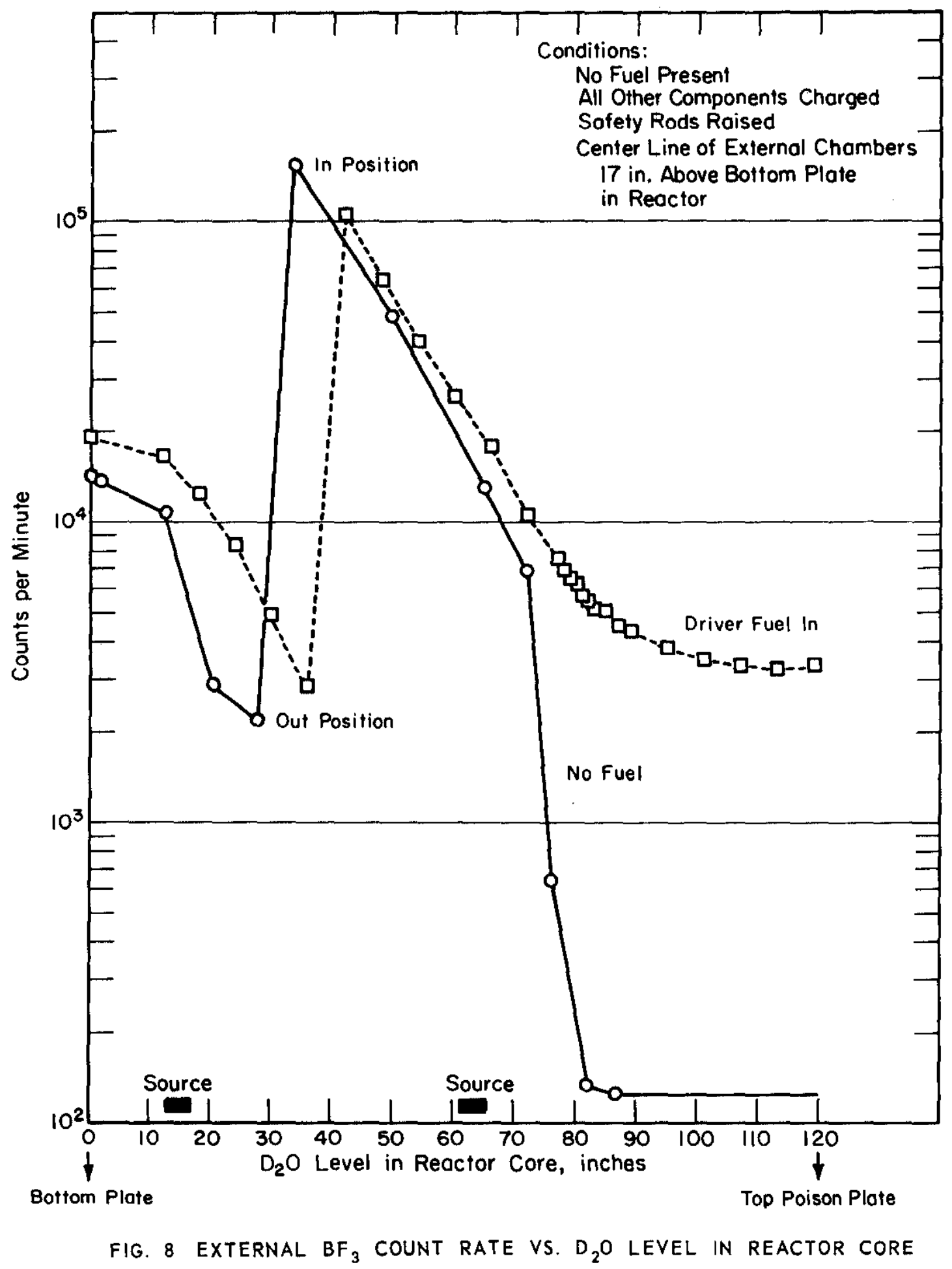


After criticality was attained, a test was conducted to determine if the in-core sections of the control rods and safety rods were properly connected or "latched" to the upper racks and extensions, which operate the axial position indicators. Two safety rods were found delatched, i.e., the rods were fully inserted in the reactor. The reactor was shut down, the two safety rods were latched, and criticality was again attained.

The banked ring control rod positions at the second criticality was 733 veeder units. The reactivity added in ralsing the $12 \mathrm{ring}$ control rods from 1000 to 733 veeder units was about $0.055 \mathrm{~K}$. Thus, the reactivity added in cluster and ring control rods to attain criticality was about $0.08 \mathrm{~K}$. The "margin of control" of the HWCTR is defined as the amount by which the reactor is subcritical at $20^{\circ} \mathrm{C}$ with the safety rods fully removed and all control rods fully inserted. In this case, the margin of control was $0.08 \mathrm{~K}$. The minimum satisfactory margin conservatively set for the initial critical was $0.04 \mathrm{~K}$.

Natural uranium fuel elements were charged to ten of the test lattice positions, excluding the pressure tubes. The reactor was made critical at 793 veeder units of ring control rod at $20^{\circ} \mathrm{C}$. The margin of control in this lattice was $0.045 \mathrm{~K}$.

Soon after the zero power tests began, a reactivity-hydraulic relationship was discovered. The reactivity of the lattice was influenced by changes in system pressure and by operation of pumps. Investigation showed that helium gas bubbles were entrained in the reactor core when the main system pumps were operating. A description of this problem and the system modifications made to eliminate it are given in reference 4. Reactivity data presented in this report were obtained after the problem was eliminated. 


\section{REACTIVITY WORTH OF CONTROL SYSTEM}

\section{Ring Control Rods}

Several tests were conducted to measure the worth of the ring control rods, and the negative reactivity effects resulting from raising the moderator temperature. Duplicate tests were conducted in a lattice containing driver fuel, then driver fuel and test fuel.

The banked, critical ring control rod configuration was measured at several moderator temperatures during a temperature ascension to $240^{\circ} \mathrm{C}$. Heat was added to the reactor system by operating the main system pumps at full flow, with no heat removal capacity in the secondary system. The control rod positions as a function of moderator temperature are shown in Figure 9.

Measurements of the worth of a single control rod were made at a moderator temperature of $240^{\circ} \mathrm{C}$. The technique used was to determine by period measurements the reactivity introduced when ring control rod No. I was removed several veeder units at each of several axial positions. To minimize radial flux tilts, ring control rod No. 7, which is directly opposite rod No. I, was set at the same axial position as rod No. 1 prior to the period measurement. The remaining ten rods were all set at the banked rod configuration required to maintain criticality. Flgure 10 shows the banked rod configuration at each position of rods 1 and 7 where a reactivity data point was obtained.

The reactivity-period relationship used in the measurements is show in Figure 11. The delayed neutron groups include fissions from ${ }^{235} \mathrm{U}$ and ${ }^{238} \mathrm{U}$, and photoneutrons from the $(\gamma, n)$ reaction with the deuterium.

The excess reactivity measured at each rod withdrawal was divided by the total rod withdrawal in veeder units (v.u.) to obtain the reactivity per unit axial distance, or $\mathrm{K} / \mathrm{v} \cdot \mathrm{u}$. A plot of $\mathrm{K} / \mathrm{v} \cdot \mathrm{u}$. versus the average position of rod No. I during the rod withdrawal is shown in Figure 12. The area under each curve is proportional to the total rod worth. The rod worths measured by this method are given in

Tabie III.

\section{TABLE III}

Rod Worths at $240^{\circ} \mathrm{C}$ Moderator Temperature

\begin{tabular}{|c|c|c|}
\hline \multirow[b]{2}{*}{ Lattice } & \multicolumn{2}{|c|}{ Reactivity, $K$} \\
\hline & Single Rod & 12 Rods \\
\hline Driver fuel only & 0.023 & 0.276 \\
\hline Driver and test fuel & 0.020 & 0.240 \\
\hline
\end{tabular}




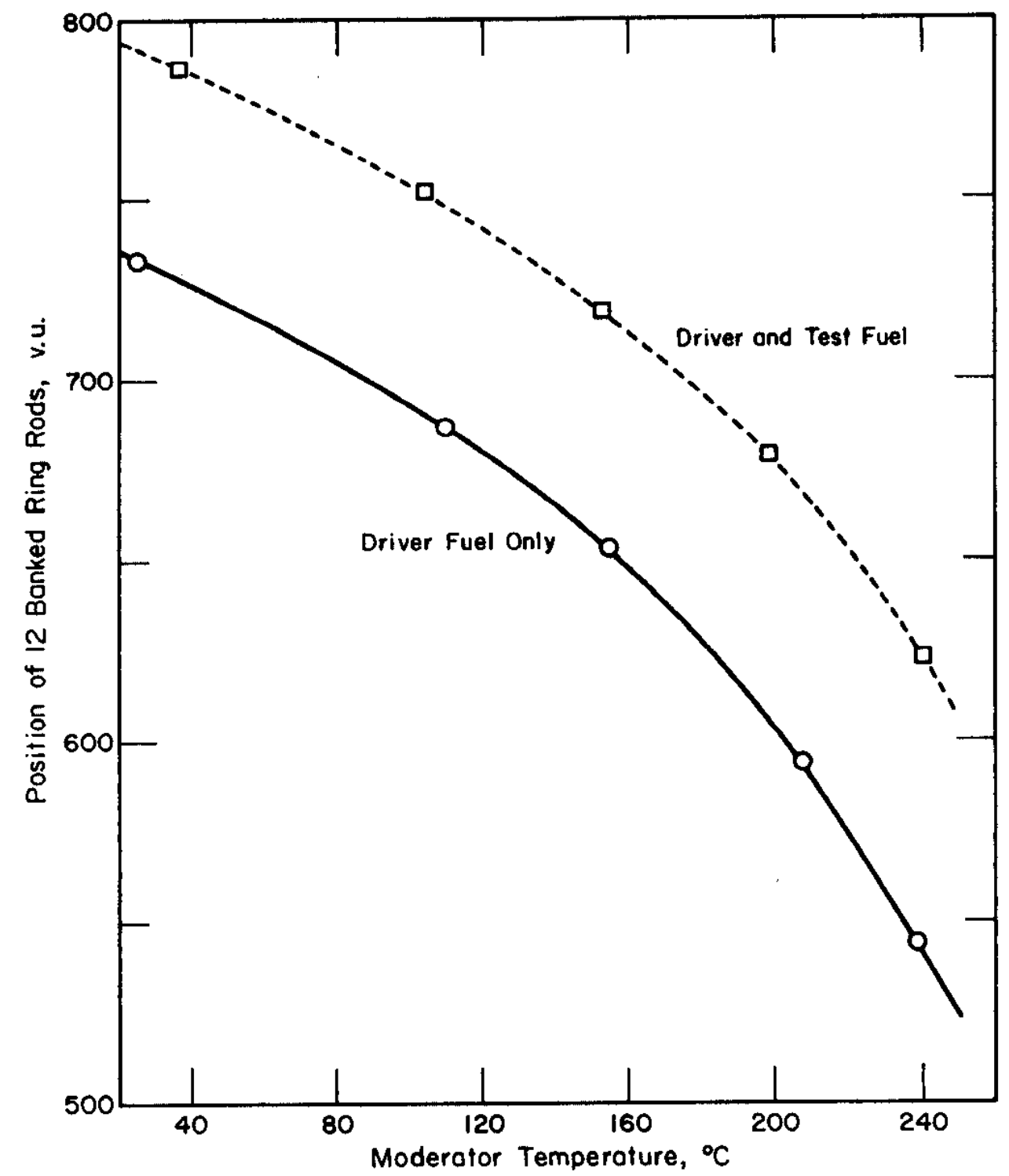

FIG. 9 AXIAL POSITION OF RING CONTROL RODS VS. MODERATOR TEMPERATURE 


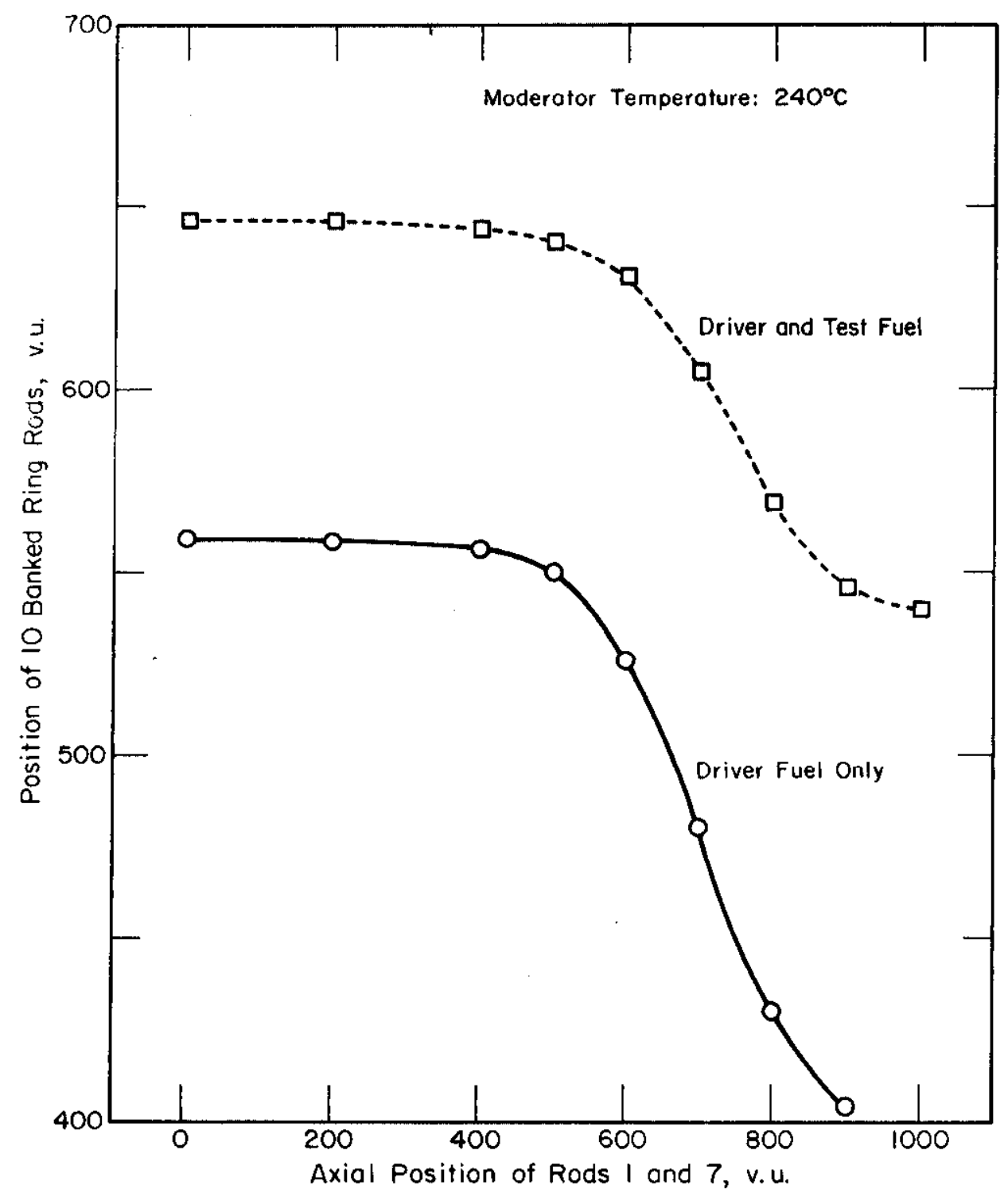

FIG. 10 AXIAL POSITION OF 10 RING CONTROL RODS VS. AXIAL POSITION OF. RODS 1 AND 7 


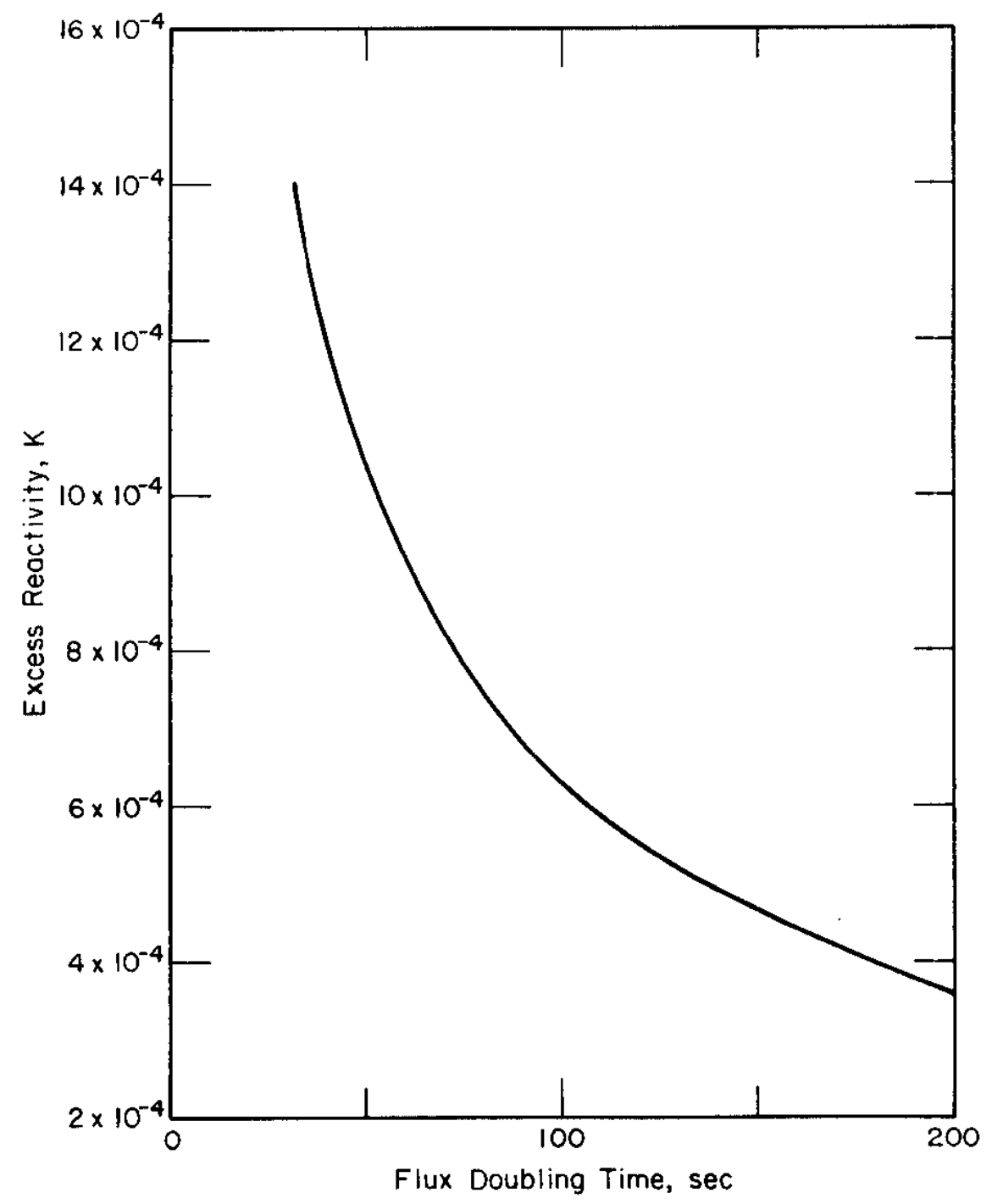

FIG. 11 EXCESS REACTIVITY VS. FLUX DOUBLING TIME 


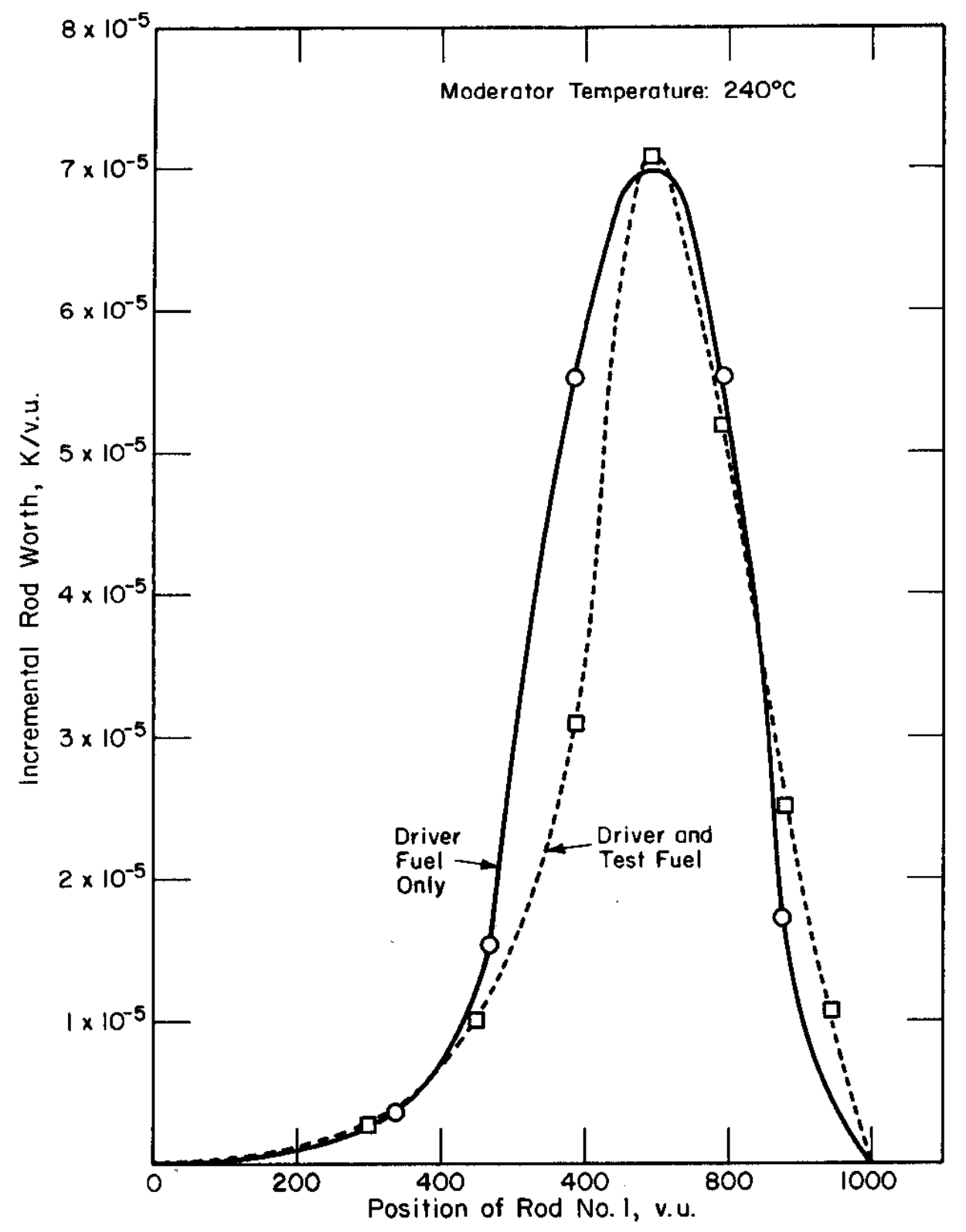

FIG. 12 INCREMENTAL ROD WORTH VS. POSITION OF ROD No. 1 
The worth of the control system as a function of moderator temperature was obtained from the measured values given above and from calculated changes in the migration area, $\mathrm{M}^{2}$. Measurements of HWCTR rod worths made in a pressurized exponentlal facility (5) showed that the changes in temperature had little effect on the incremental rod buckling. Thus, the change in rod worth to the lattice should follow the change in $\mathrm{M}^{2}$. The calculated values for the worth of the $12 \mathrm{ring}$ control rods as a function of temperature are shown in Figure 13. The rod worth values at $20^{\circ} \mathrm{C}$ moderator temperature are given in Table IV.

\section{TABLE IV}

Rod Worths at $20^{\circ} \mathrm{C}$ Moderator Temperature

\begin{tabular}{|c|c|c|}
\hline \multirow[b]{2}{*}{ Lattice } & \multicolumn{2}{|c|}{ Reactivity, $\mathrm{K}$} \\
\hline & SIngle Rod & 12 Rods \\
\hline Driver fuel & 0.020 & 0.234 \\
\hline Driver and test fuel & 0.017 & 0.200 \\
\hline
\end{tabular}

The maximum drive speed of a control rod is $2.5 \mathrm{ft} / \mathrm{min}$ or $4.4 \mathrm{v} . \mathrm{u} . / \mathrm{sec}$. If the control rod tip were in the axial region of maximum reactivity worth, the reactivity introduced at $240^{\circ} \mathrm{C}$ would be $7 \times 10^{-5} \mathrm{~K} / \mathrm{v} \cdot \mathrm{u}$. of rod motion, as shown in Figure 12. The rate of reactivity addition would be $3.1 \times 10^{-4} \mathrm{~K} / \mathrm{sec}$. The corresponding rate at $20^{\circ} \mathrm{C}$ is $2.6 \times 10^{-4} \mathrm{~K} / \mathrm{sec}$.

\section{Safety Rods}

The six safety rods are identical in composition with the control rods, and are arranged on a circle with a diameter seven inches less than the ring control rods. The effectiveness of the safety rods is dependent on the number of other rods present in the lattice. The lattice condition at which it is most meaningful to evaluate the safety rod worth is with the critical rod configuration at full operating temperature and with a moderator temperature of $20^{\circ} \mathrm{C}$. This condition simulates the abnormal sequence of events in which the reactor is scrammed from full operating temperature and the safety rods drop in, but the control rods do not drive in. HWCTR operating standards require that the negative reactivity introduced by the safety rods be sufficient to hold the reactor subcritical by at least $0.01 \mathrm{~K}$ when the system temperature reaches $20^{\circ} \mathrm{C}$. Computations made using the $P D Q-3$ routine(6) showed that the worth of the six safety rods, with the control rod complement just described, was approximately $5-1 / 2$ ring rods, or $0.09 \mathrm{~K}$ at $20^{\circ} \mathrm{C}$ moderator temperature. Thus, to 


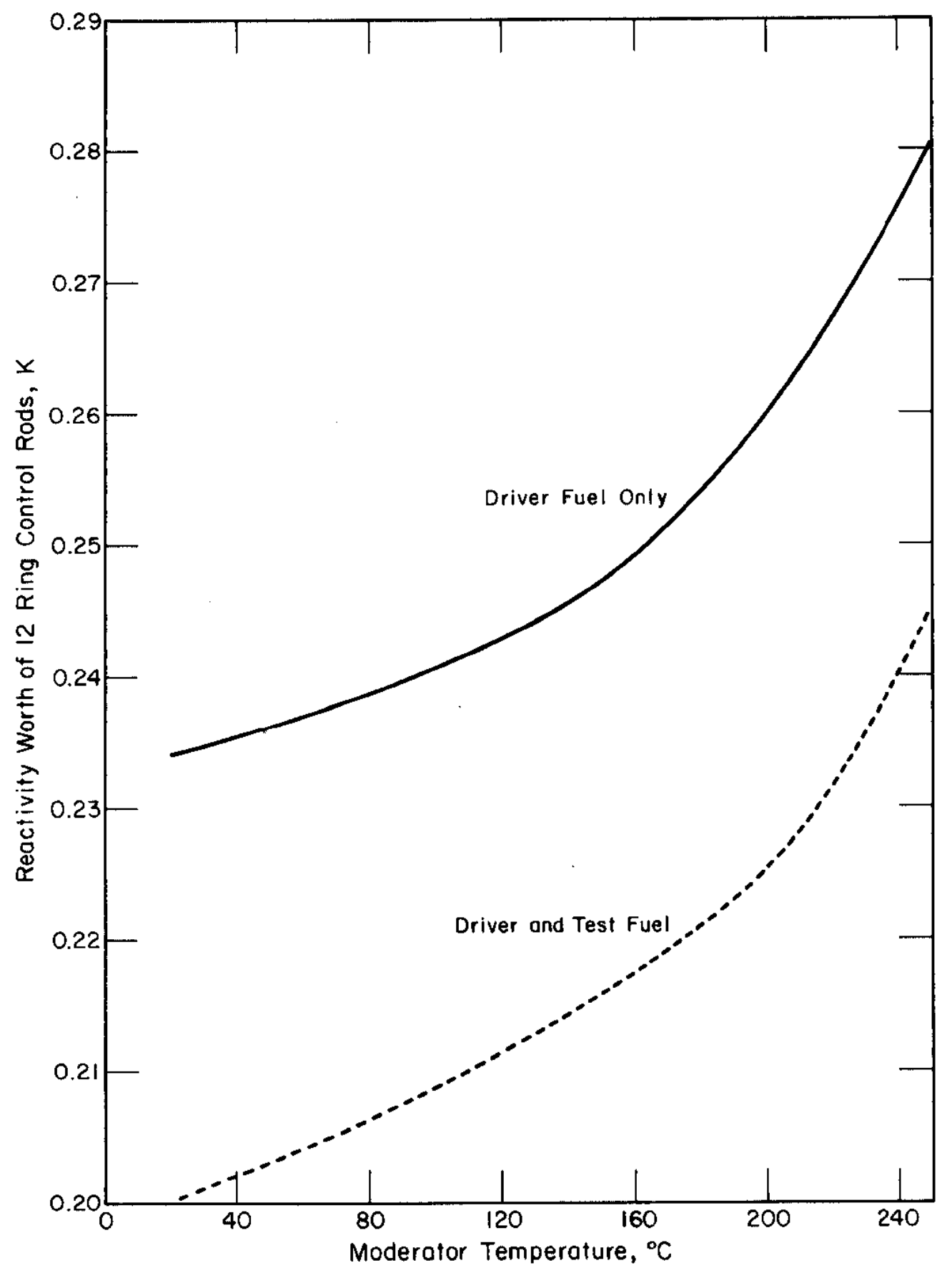

FIG. 13 REACTIVITY WORTH OF 12 RING CONTROL RODS VS. MODERATOR TEMPERATURE 
maintain the required margin of $0.01 \mathrm{~K}$, the reactivity regained when the system cools down from the operating temperature to $20^{\circ} \mathrm{C}$ must not exceed $0.08 \mathrm{~K}$. The value of $0.08 \mathrm{~K}$ in temperature reactivity effects set the upper limit on the allowable operating temperature for the lattice contalning driver and test fuel.

Two methods were used to determine the maximum allowable operating temperature. In the first, a fractional rod worth curve was prepared, for use with the banked control rod data. In the second method, control rod complements of fully inserted rods were compared at hot and ambient temperature conditions.

The fractional rod worth curve was prepared from calculations made using the PDQ-2 routine, $(7)$ and from data obtained in period measurements. The curve is presented in Figure 14. The rod worth fraction that may be used to raise the moderator temperature from $20^{\circ} \mathrm{C}$ to the limiting temperature is equal to the ratio of $0.08 \mathrm{~K} / 0.20 \mathrm{~K}$, or 0.40 . Figure 14 shows that rod removal from $793 \mathrm{v} \cdot \mathrm{u} .\left(20^{\circ} \mathrm{C}\right)$ to $610 \mathrm{v} . \mathrm{u}$. is equivalent to the rod worth fraction of 0.40 . Figure 9 shows that the moderator temperature was $250^{\circ} \mathrm{C}$ at a rod position of $610 \mathrm{v} \cdot \mathrm{u}$. Thus, the limiting moderator temperature is $250^{\circ} \mathrm{C}$.

The difference in the number of fully inserted control rods between the $20^{\circ} \mathrm{C}$ and $250^{\circ} \mathrm{C}$ moderator temperature was approximately 5 rods. The effective worth of the six safety rods was approximately $5-1 / 2$ rods. A margin of $0.01 \mathrm{~K}$, approximately $1 / 2$ rod, is required by HWCTR operating standards. Thus, the Iimiting moderator temperature for the driver and test lattice is $250^{\circ} \mathrm{C}$, as determined also by the second method.

The limiting temperature for the driver only lattice was not evaluated in detail, but was shown to be higher than $250^{\circ} \mathrm{C}$. The effectiveness of the safety rods in the lattice with driver fuel only is larger than in the combined driver and test fuel lattice.

Calculations show that a small increase in the limiting moderator temperature occurs with fuel depletion. The reactivity required to conduct the temperature ascension increases with fuel depletion, but the worth of the safety rods also increases, at a sllghtly higher rate.

The worth of the six safety rods in the shutdown lattice could not be measured directly and was not evaluated in detall. The safety rod worth was less than the $0.09 \mathrm{~K}$ value given for the specific lattice conditions described earlier. Estimates made from a brief study show that the reactivity added by the removal of the six safety rods prior to a nuclear startup was 0.06 to $0.07 \mathrm{~K}$. Thus, a reactor charge with a measured margin of control of $0.04 \mathrm{~K}$ has a $\mathrm{K}$ eff value of $0.90 \mathrm{~K}$, or less, in the completely shutdown condition. 


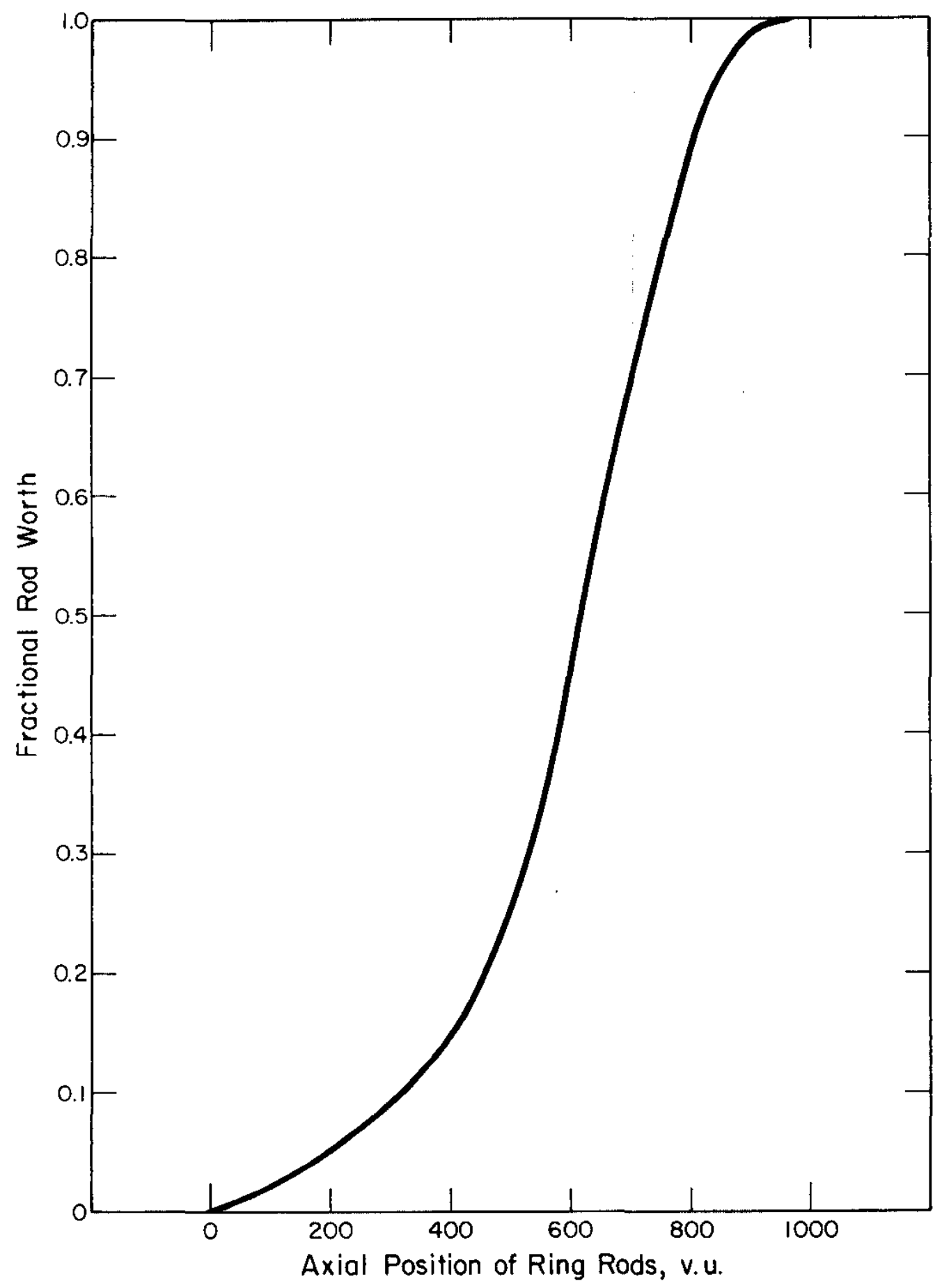

FIG. 14 FRACTIONAL ROD WORTH VS. AXIAL POSITION OF RING RODS Driver and Test Fuel 


\section{Center Cluster Control Rods}

The measured worth of the center cluster control rods was less than the calculated value and less than the value obtained in the PDP mockup tests. (3) Insertion of the cluster rods required that the banked ring control rods be removed from $793 \mathrm{v} . \mathrm{u}$. to $746 \mathrm{v} . \mathrm{u}$. The rod worth curve in Figure 14 shows that the 47 veeder units of rod motion is equal to $0.02 \mathrm{~K}$. Calculations showed the worth of the cluster rods to be 0.025 to $0.030 \mathrm{~K}$. The PDP mockup tests showed the worth of the cluster rods to be 0.030 to $0.035 \mathrm{~K}$.

The cluster control rods serve only to provide additional shutdown margin and were not used to control the reactor during operation at full power. A conservative value of $0.020 \mathrm{~K}$ was used for the cluster rod worth in margin of control calculations. The corresponding value used for the driver only lattice was $0.025 \mathrm{~K}$. The reference moderator temperature in margin of control calculations was $20^{\circ} \mathrm{C}$.

\section{TEMPERATURE COEFFICIENT OF REACTIVITY}

A measure of the increase in neutron leakage from the reactor with moderator temperature increases may be obtained by combining the banked rod data shown in Figure 9, the total rod worths at each temperature from Figure 13, and the fractional rod worths from Figure 14. of more practical interest, however, is the moderator temperature effect related to the kinetic response of the reactor. An outstanding safety feature of the HWCTR is its large, negative moderator temperature coefficient. Two general effects contribute to the coefficient the increase in neutron leakage and the increase in rod worth with increasing moderator temperature. The most direct method of obtaining a measure of the coefficients from the data obtained is to combine the banked control rod data of Figure 9 with the fractional rod worth curve of Figure 14, and to $\mathrm{fix}$ the total rod worth value at the $20^{\circ} \mathrm{C}$ value of $0.20 \mathrm{~K}$. The rates of change of the reactivity differences obtained in this manner are equal to the temperature coefficients, which are temperature dependent. The results are shown in Figure 15.

The temperature coefficient at the normal operating temperature of $250^{\circ} \mathrm{C}$ was $-7 \times 10^{-4} \mathrm{~K} /{ }^{\circ} \mathrm{C}$.

\section{FLUX DISTRIBUTIONS}

The radial and axial flux distributions were measured for several control rod configurations by irradiating copper wires. Ten-foot lengths of copper wire were inserted in each fuel element, and the reactor was operated at a power of a few kilowatts. The activity of 


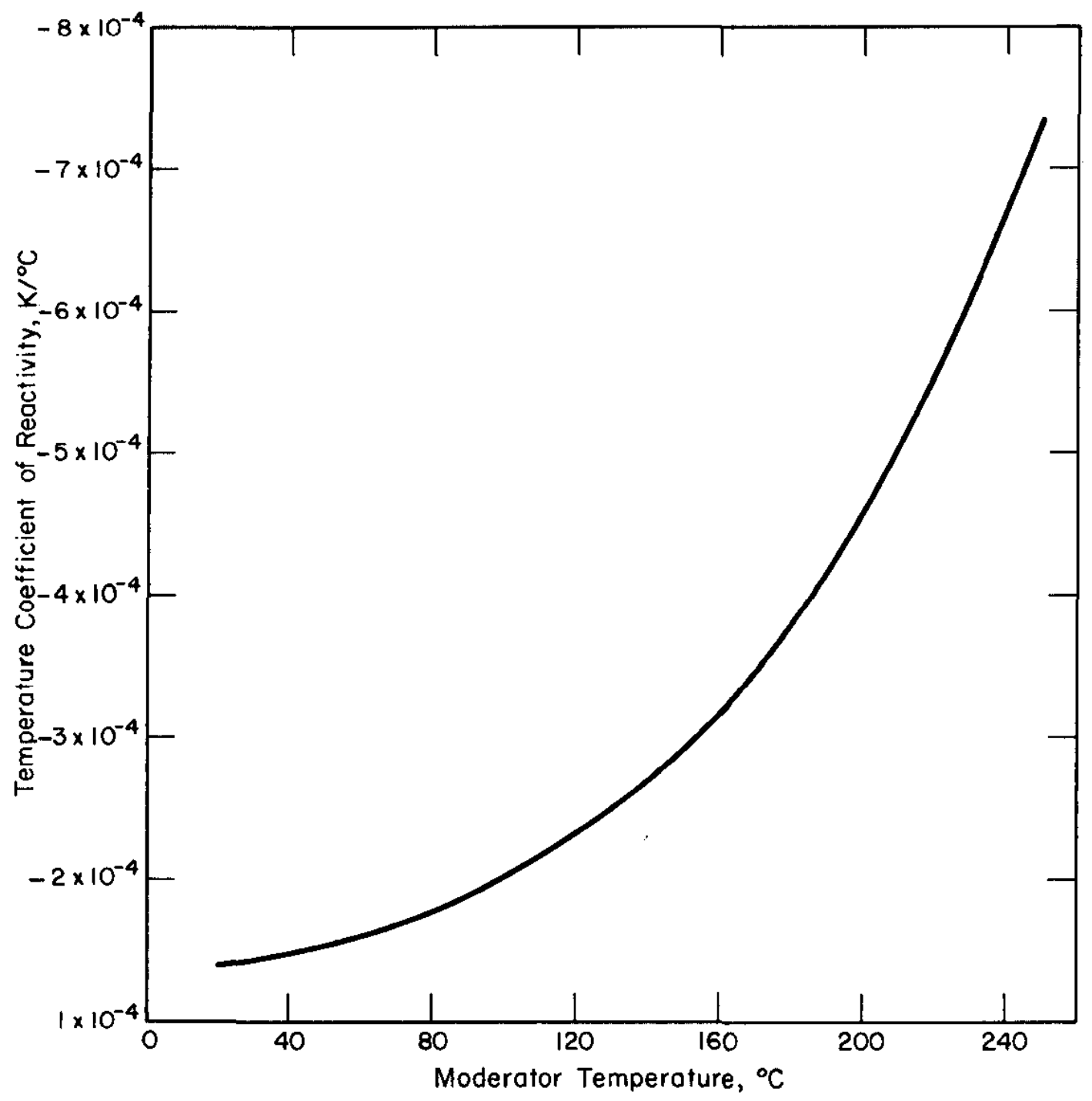

FIG. 15 TEMPERATURE COEFFICIENT OF REACTIVITY VS. MODERATOR TEMPERATURE 
each wire was measured by a moving scintillation probe. The recorder trace was a profile of the axial flux distribution, and the area under the trace was proportional to the integrated radial flux at the fuel element.

\section{Radial Flux}

The results of the radial flux measurements are shown in Figure 16 through 24. The values given at each fuel position represent the average, relative flux in the fuel tube. Calculated disadvantage factors were used to convert the wire flux value to fuel tube flux, a correction of only $3 \%$.

Figure 16 shows the relative flux distribution with all ring control rods positioned at 793 veeder units and all cluster rods removed. Some asymmetries in radial flux are apparent. Fuel elements $180^{\circ}$ apart do not necessarily have the same flux value. The maximum driver element flux was $8 \%$ above the average driver flux. The average test element flux was $66 \%$ above the average driver flux.

Figure 17 shows the results of the wire irradiation run made with the odd numbered ring control rods set at $1000 \mathrm{v} . \mathrm{u} .$, and the even numbered rods set at 662 v.u.

Figure 18 shows that the average flux in the inner test fuel was reduced $30 \%$ by the complete insertion of the center cluster rods.

The flux peak resulting from the complete removal of a ring control rod is shown in Figure 19. The maximum driver flux was 1.21, compared to a value of 1.08 measured when all ring control rods were banked.

The severe radial flux tilt that is shown in Figure 20 demonstrates that opposing rod pairs must be set at the same axial position. The high side of the tilt was centered in driver group 21, 22, 23, and 24, with the low side in the corresponding four drivers on the opposite side of the lattice. The only difference in the axial position of opposite control rod pairs that could create the tilt is in ring rods 2 and 8 . Rod 8 was fully inserted, but rod 2 was inserted only to 700 v.u. Other opposing rod pairs were either at the same axial position or were oriented at right angles to the line of the tilt.

In the final wire irradiation run made at ambient temperature, the reactor was taken critical on only two control rods, rods 1 and 2 , which were removed to $437 \mathrm{v} . \mathrm{u}$. As shown in Figure 21, the flux in the driver fuel on the high side of the tilt was almost $2-1 / 2$ times the flux on the low side of the tilt. 


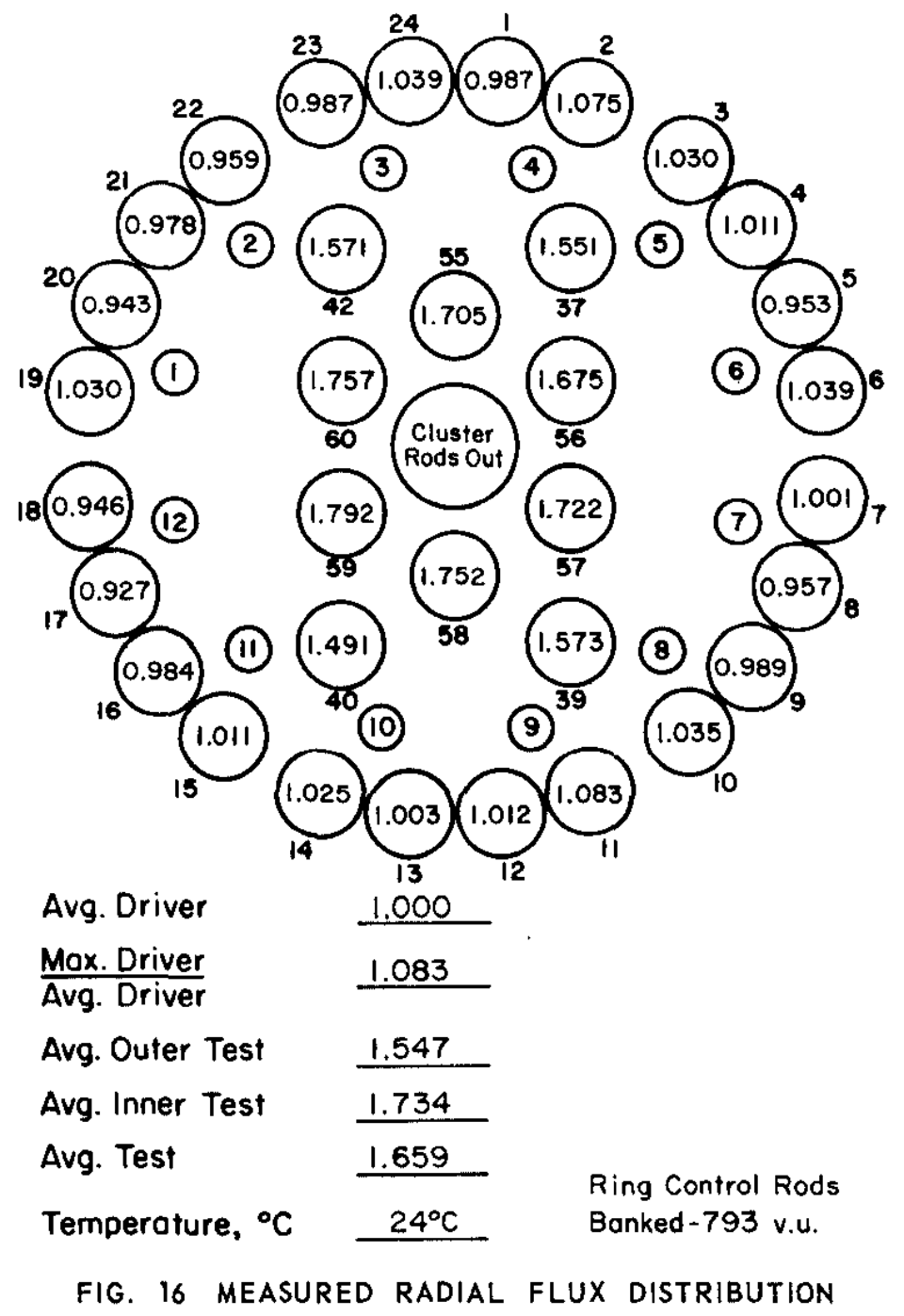




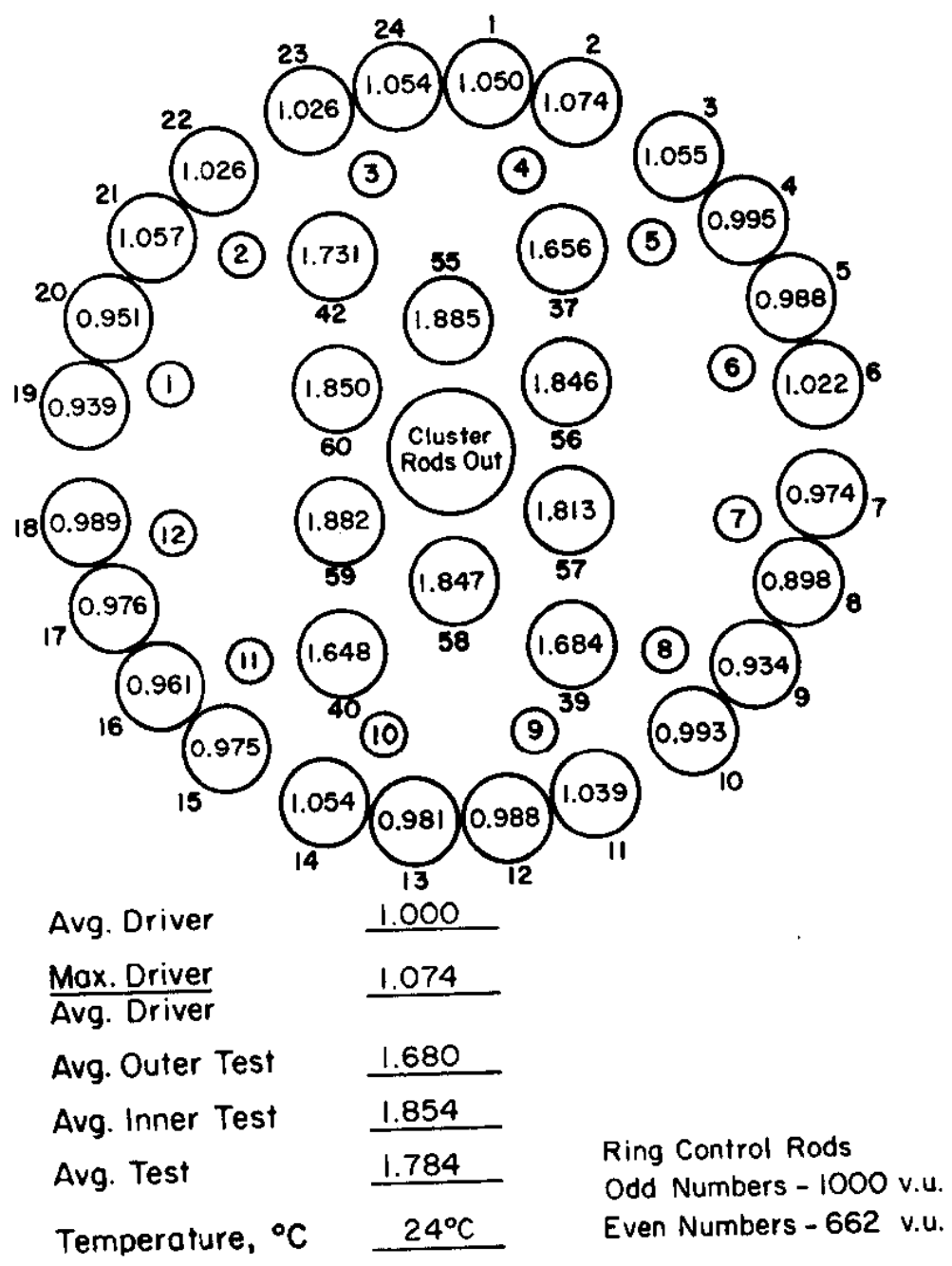

FIG. 17 MEASURED RADIAL FLUX DISTRIBUTION 


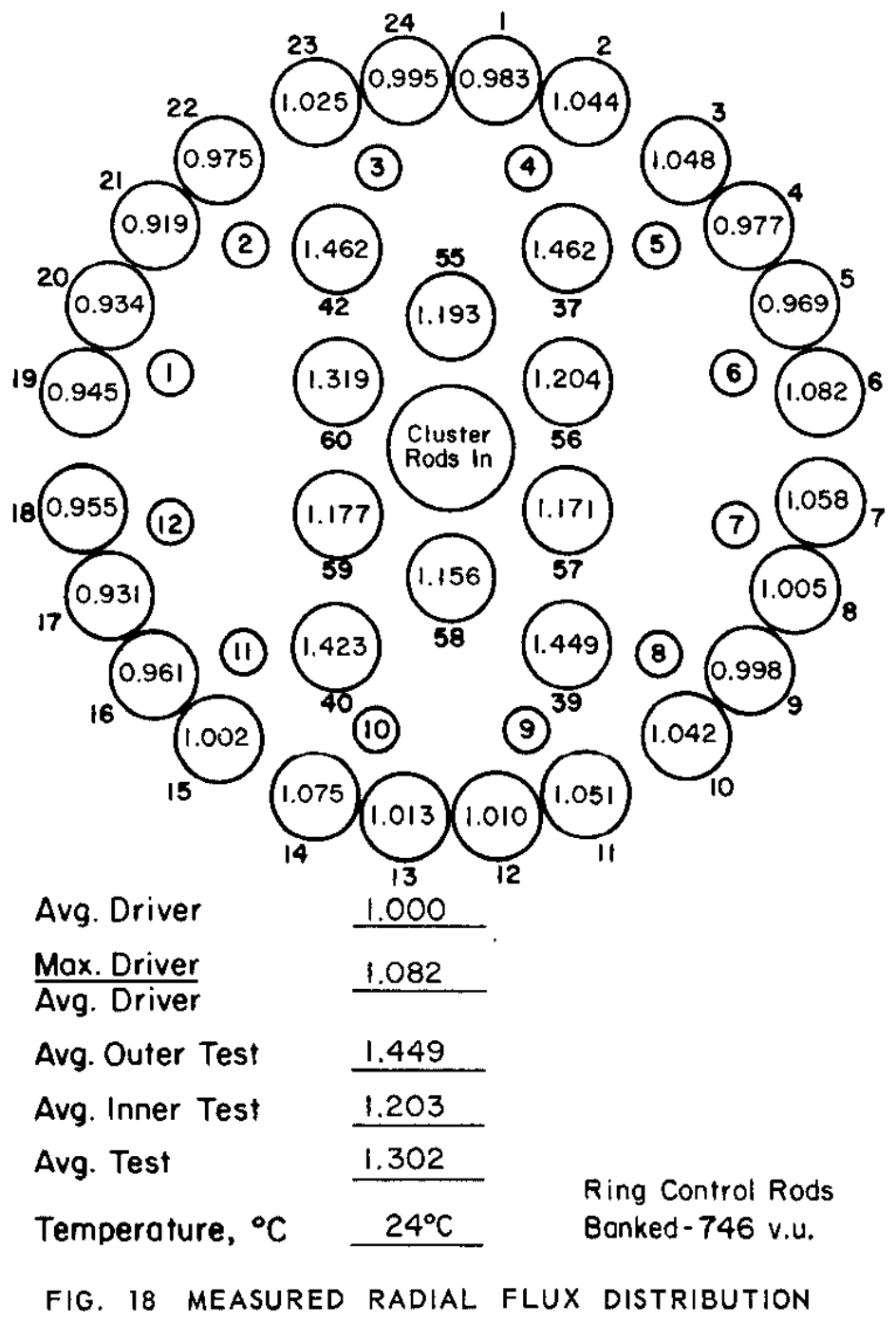




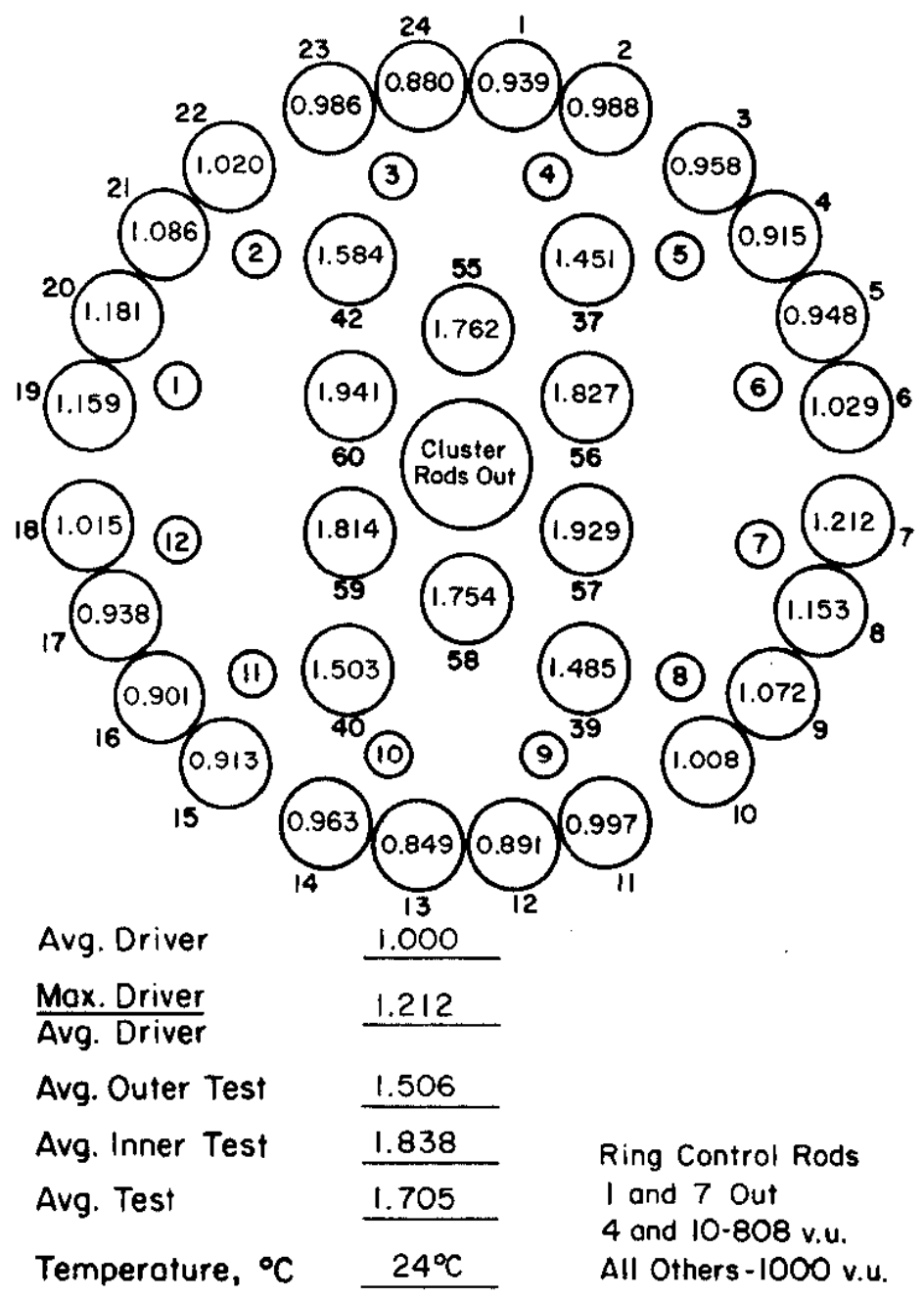

FIG. 19 MEASURED RADIAL FLUX DISTRIBUTION 


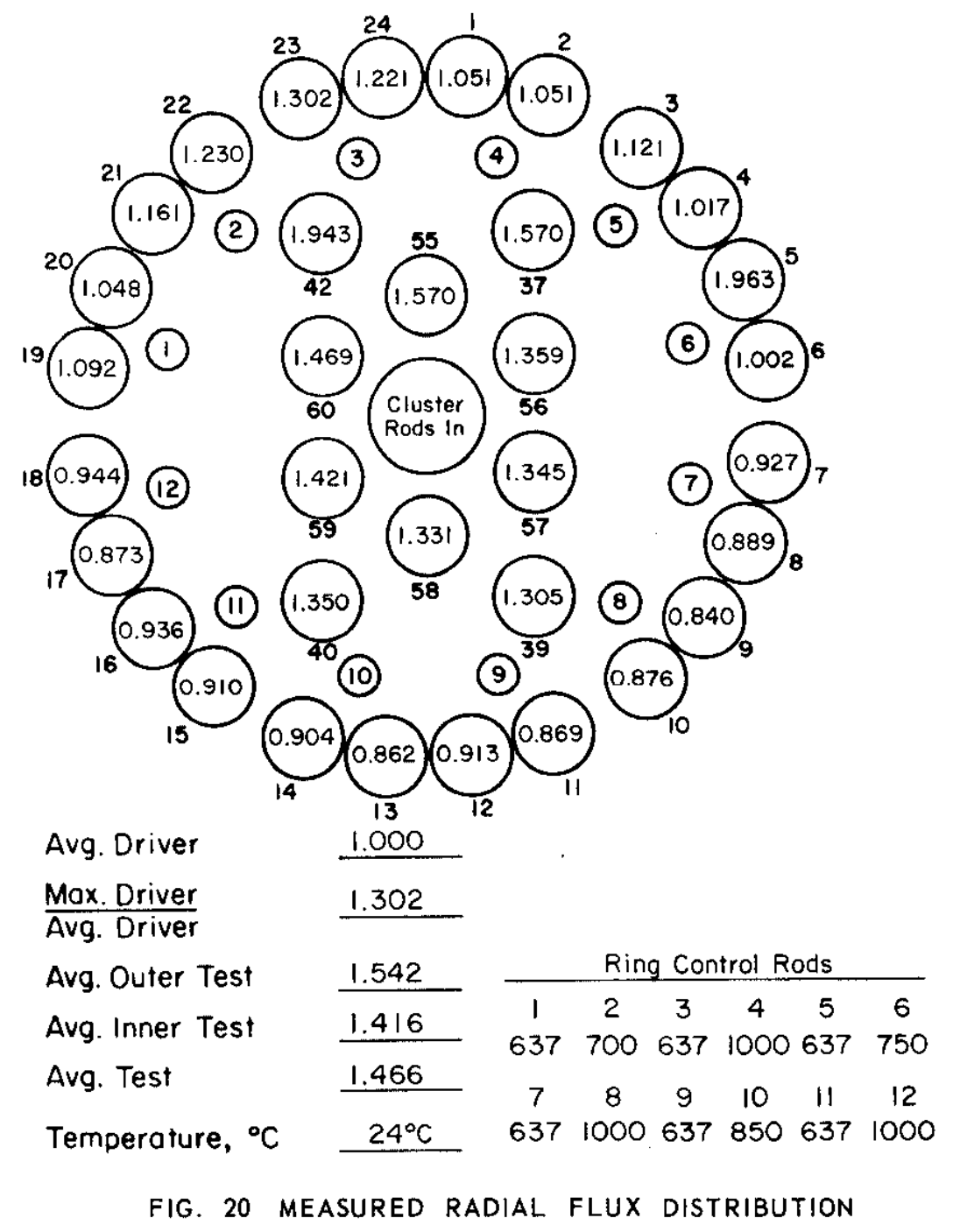




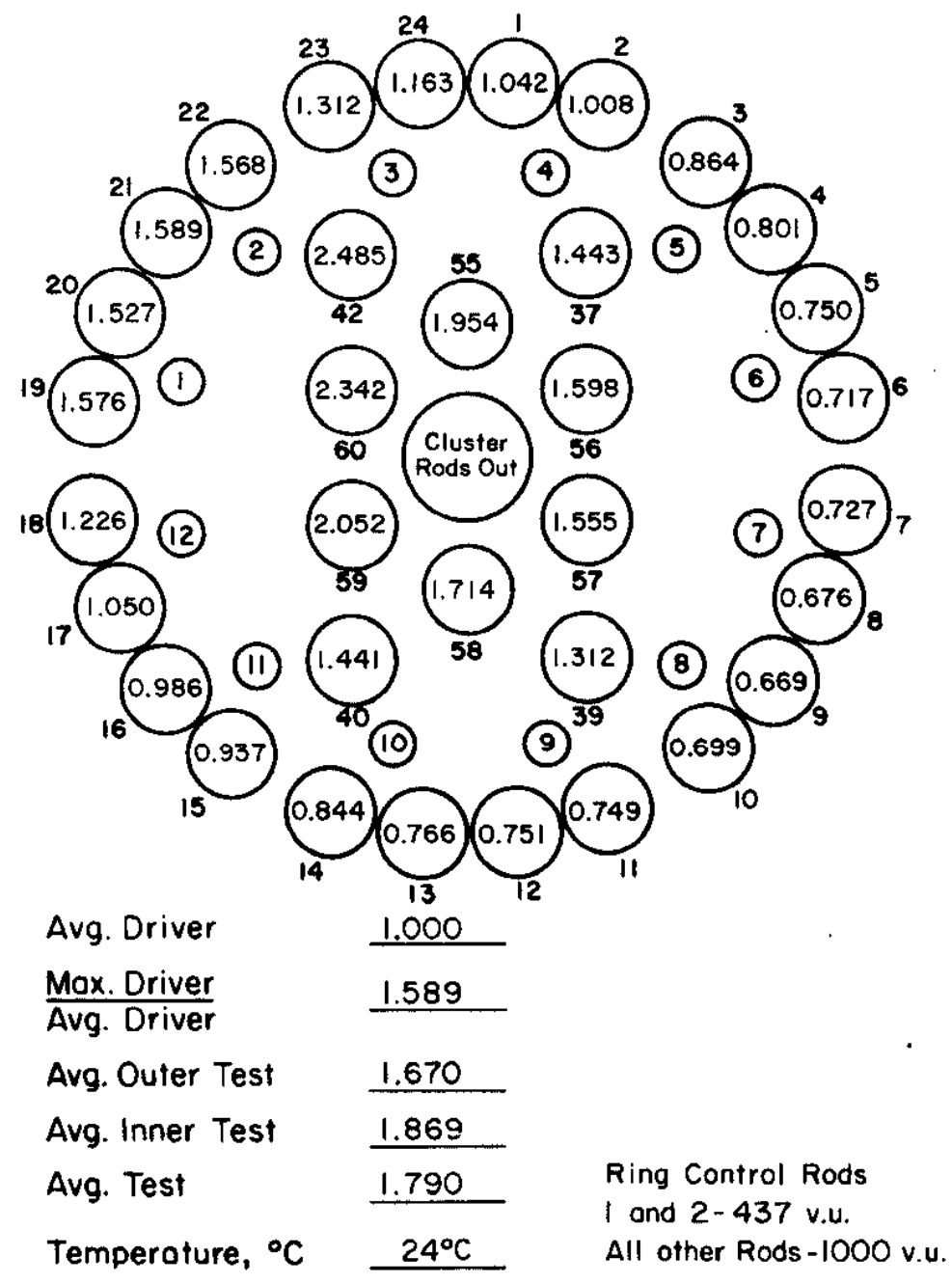

FIG. 21 MEASURED RADIAL FLUX DISTRIBUTION 
Three wire irradiation runs were made near the anticipated operating temperature of $240^{\circ} \mathrm{C}$. The results of these three runs are shown in Figures 22, 23, and 24. The most important results of these measurements were that the highest driver flux was only $5 \%$ above the average, and that the average test flux was $68 \%$ above the average driver flux when the 12 ring control rods were banked. A similar test flux value was measured at $24^{\circ} \mathrm{C}$ (Figure 16 ).

Computational models were developed to permit the calculation of radial and axial flux distributions. The $X Y$ version of $P D Q-3^{(0)}$ was used for the radial model, and the RZ version of $P D Q-2(7)$ was used for the axial model. The core configurations in the two models are shown in Figures 25 and 26.

In the radial model, fuel elements and control rods were represented as square cells surrounded by moderator. Input parameters for the cells in the PDQ-3 routine were obtalned from MUFT $\mathrm{IV}^{(8)}$ calculations and calculations using the $P_{3}$ approximation to transport theory. A constant axial buckling was assigned.

Only two comparisons of calculated and measured flux distributions were made. The measured data were already described in Figures 16 and 17. The calculated distributions are shown in Figures 27 and 28 . In the first comparison, input parameters for the control rods and center cluster housing were adjusted to yield a test to driver flux ratio in agreement with the measured flux ratio. The calculated driver flux distribution was symmetrical about two axes, so that four driver positions shared a single relative flux value. In the second calculated distribution, driver elements $180^{\circ}$ apart had the same relative flux value.

No satisfactory method was developed for obtaining PDQ-3 input parameters for partially inserted control rods, different from the banked rod position. No comparison of measured and calculated radial flux distributions was made for most of the rod configurations shown in Figures 16 through 24. During power operation of the HWCTR, the ring control rods were all set at the same axial position. Application of the radial model was used in these instances to predict the operating conditions of test fuel elements of new design.

\section{Axial Flux}

The axial computational model was developed to permit the calculation of axial flux distributions as a function of control rod position. Because the HWCTR contained no in-core flux monitors, the determination of maximum operating conditions was made directly from 
calculated axial flux distribution. (The total power of each fuel element was measured from flow and $\Delta T$ instruments.) The fuel and control rod regions of the axial model, shown in Figure 26, were composed of concentric cylinders in the two-dimensional geometry. The lower boundary of the control rod regions could be set at any elevation, to simulate partial insertions of banked rods. The input parameters for the control rod region were determined empirically from the results of the wire irradiations at low power. A comparison of the calculated and measured axial flux profiles is shown in Figures 29 and 30 .

The calculation of axlal flux profiles with fuel exposure was made using the TURBO(g) code. TURBO utilizes the PDQ-2 routine to calculate flux distributions. Fuel burnup in TURBO was achleved in short time increments with the new input parameters for the PDQ-2 routine computed at the end of each time increment.

The heterogeneous properties of the HWCTR lattice can be best represented in a three-dimensional model. The best candidate for this application is the TRIHET code, (10) but no work with this code has been completed. 


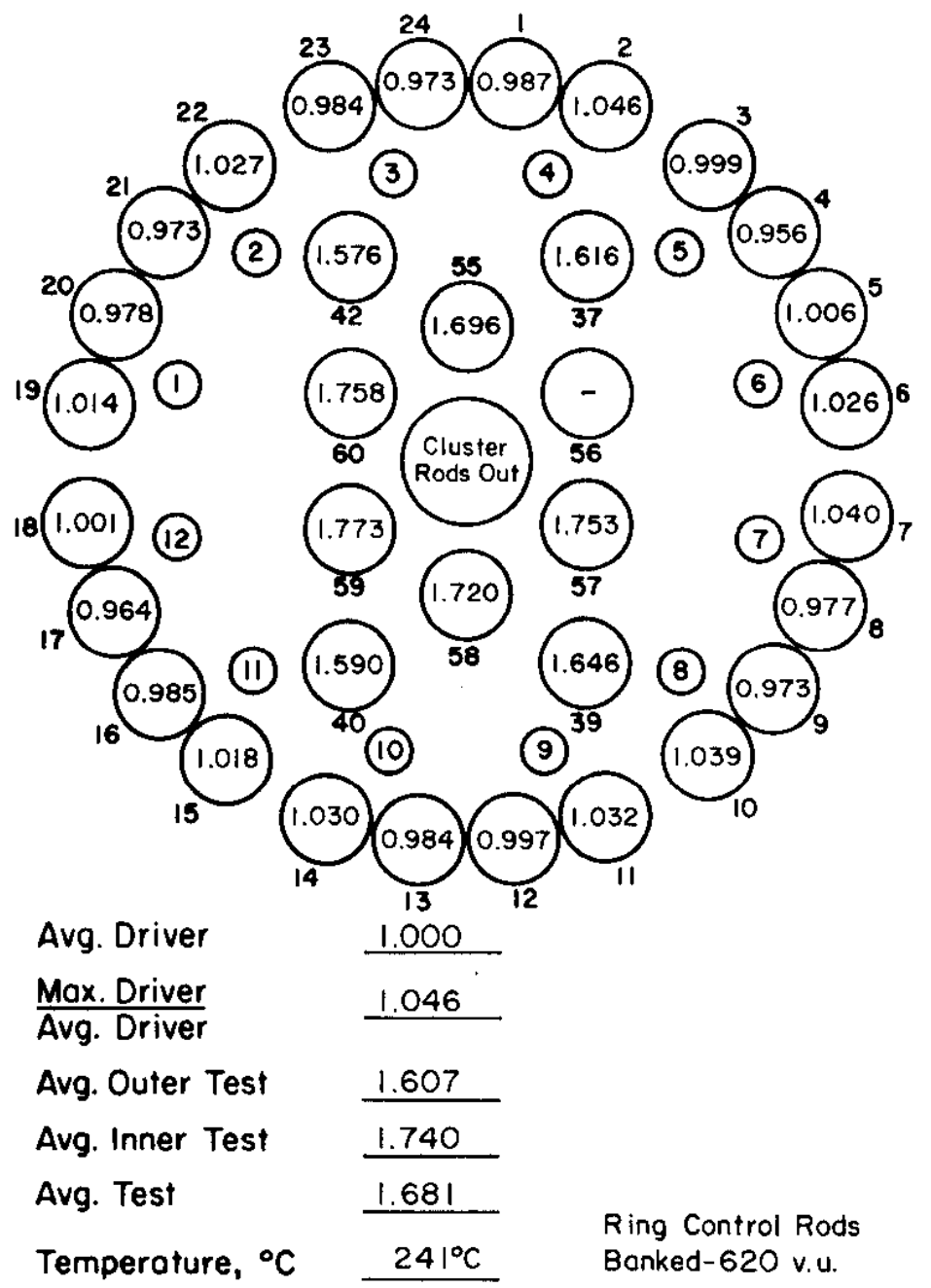

FIG. 22 MEASURED RADIAL FLUX DISTRIBUTION 


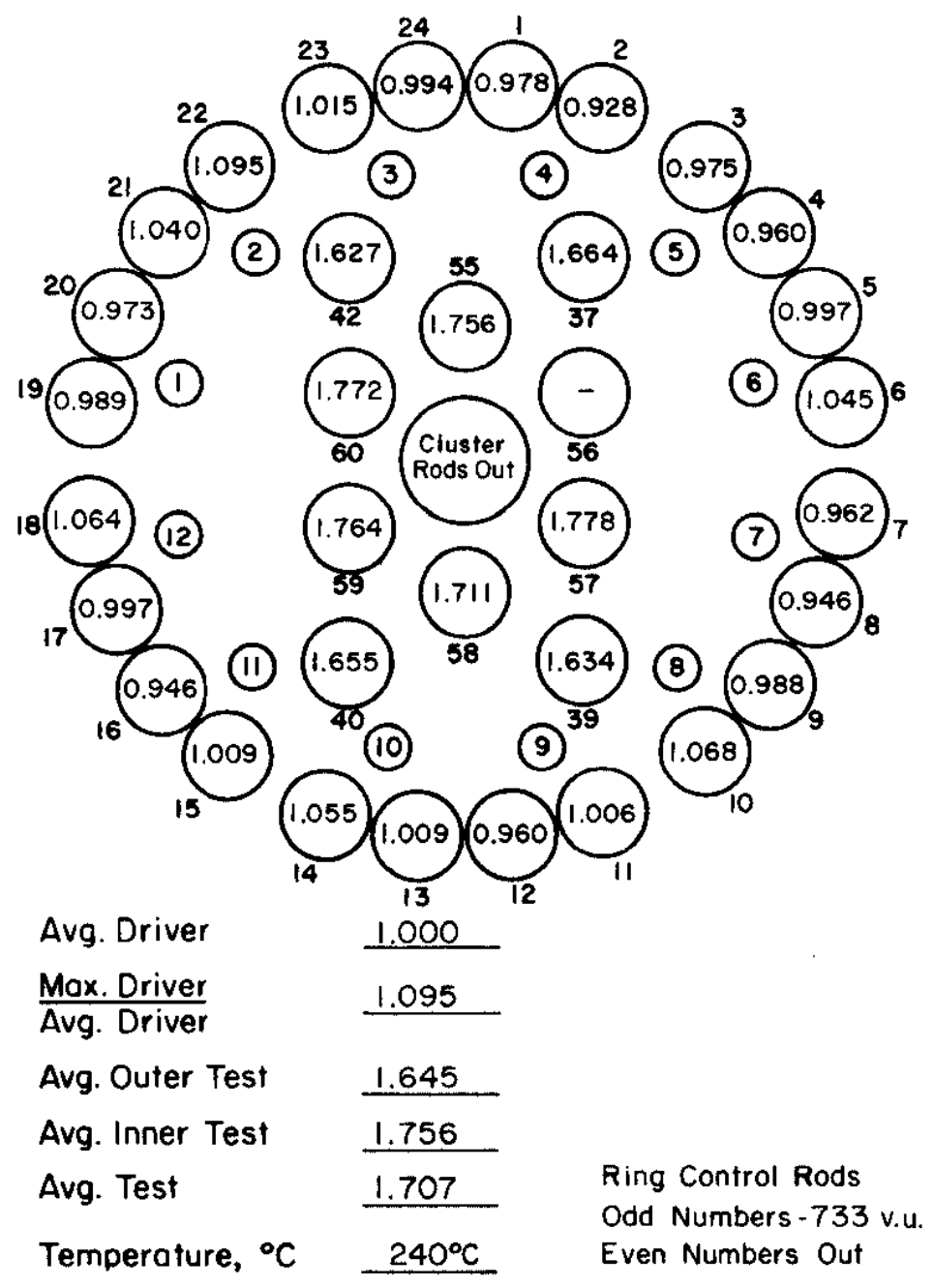

FIG. 23 MEASURED RADIAL FLUX DISTRIBUTION 


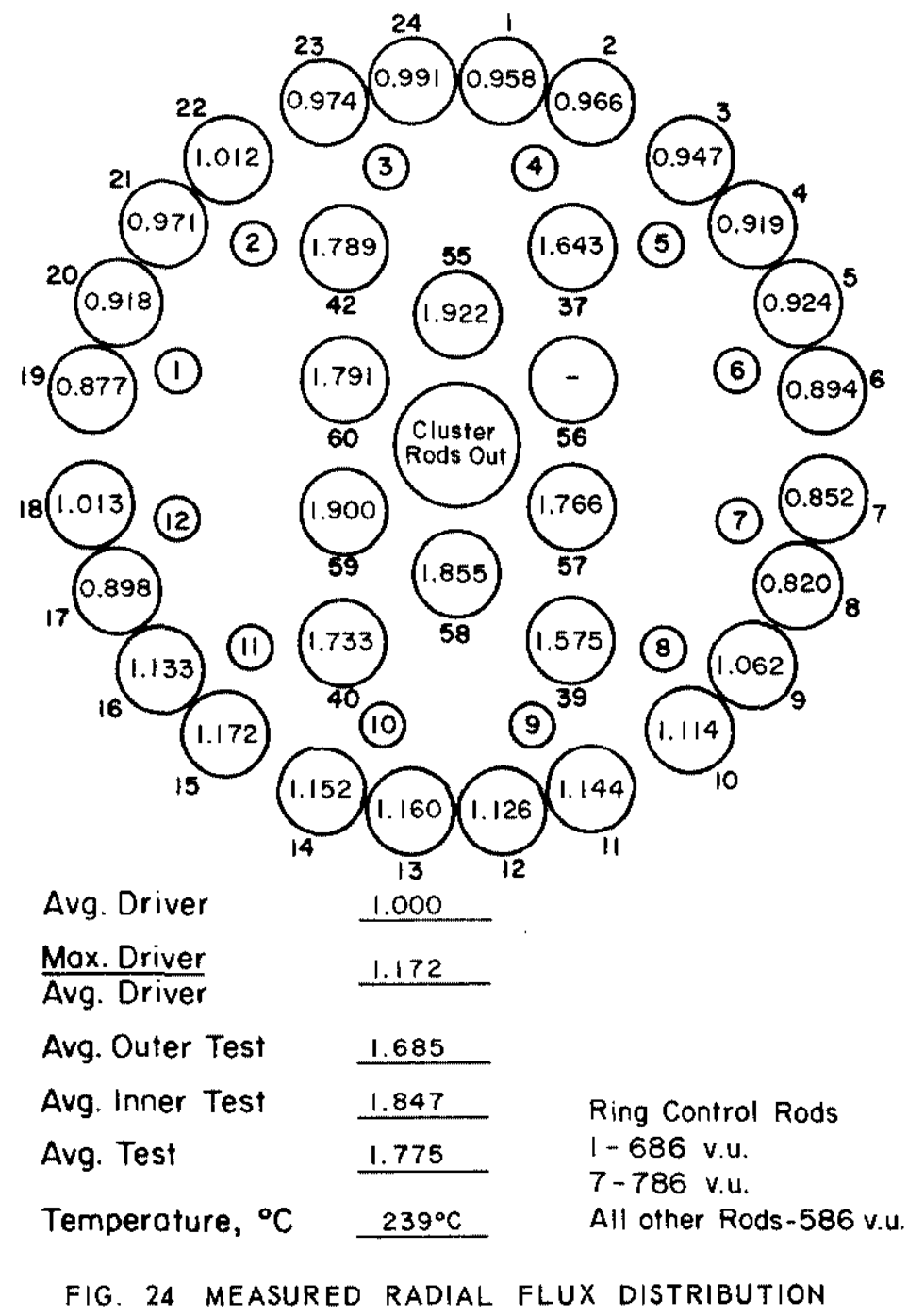




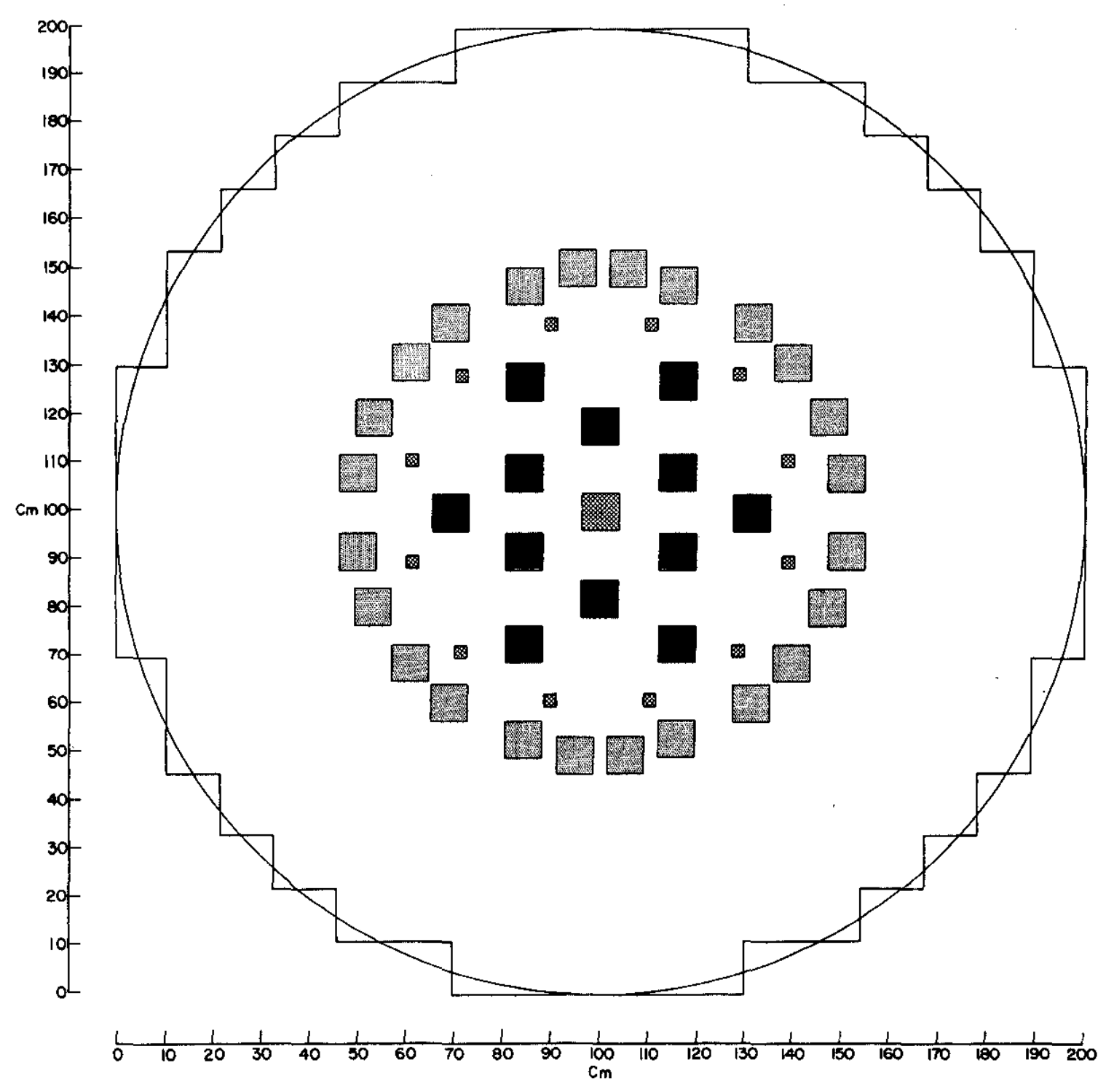

FIG. 25 RADIAL COMPUTATIONAL MODEL 


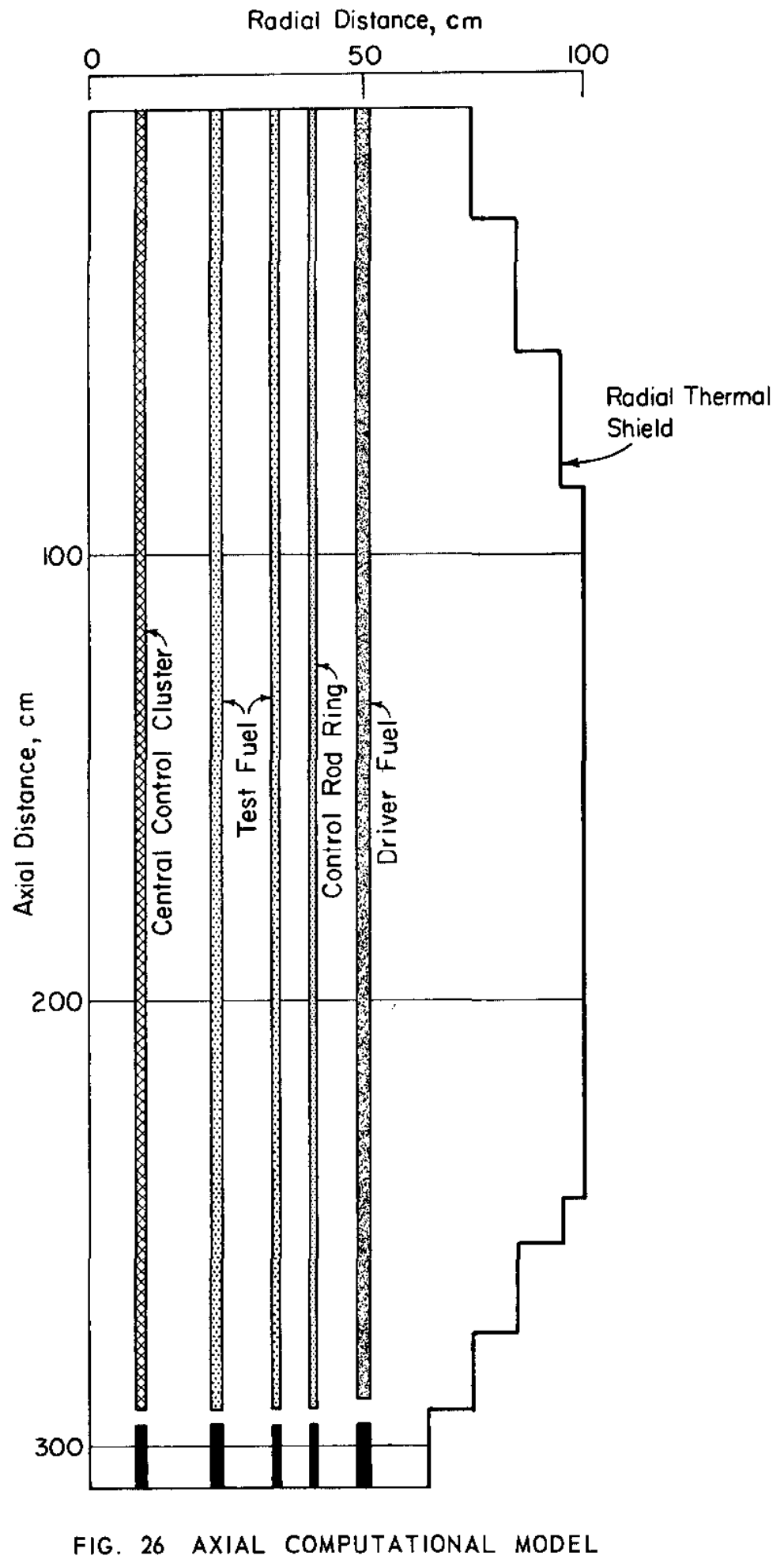

- $40-$ 


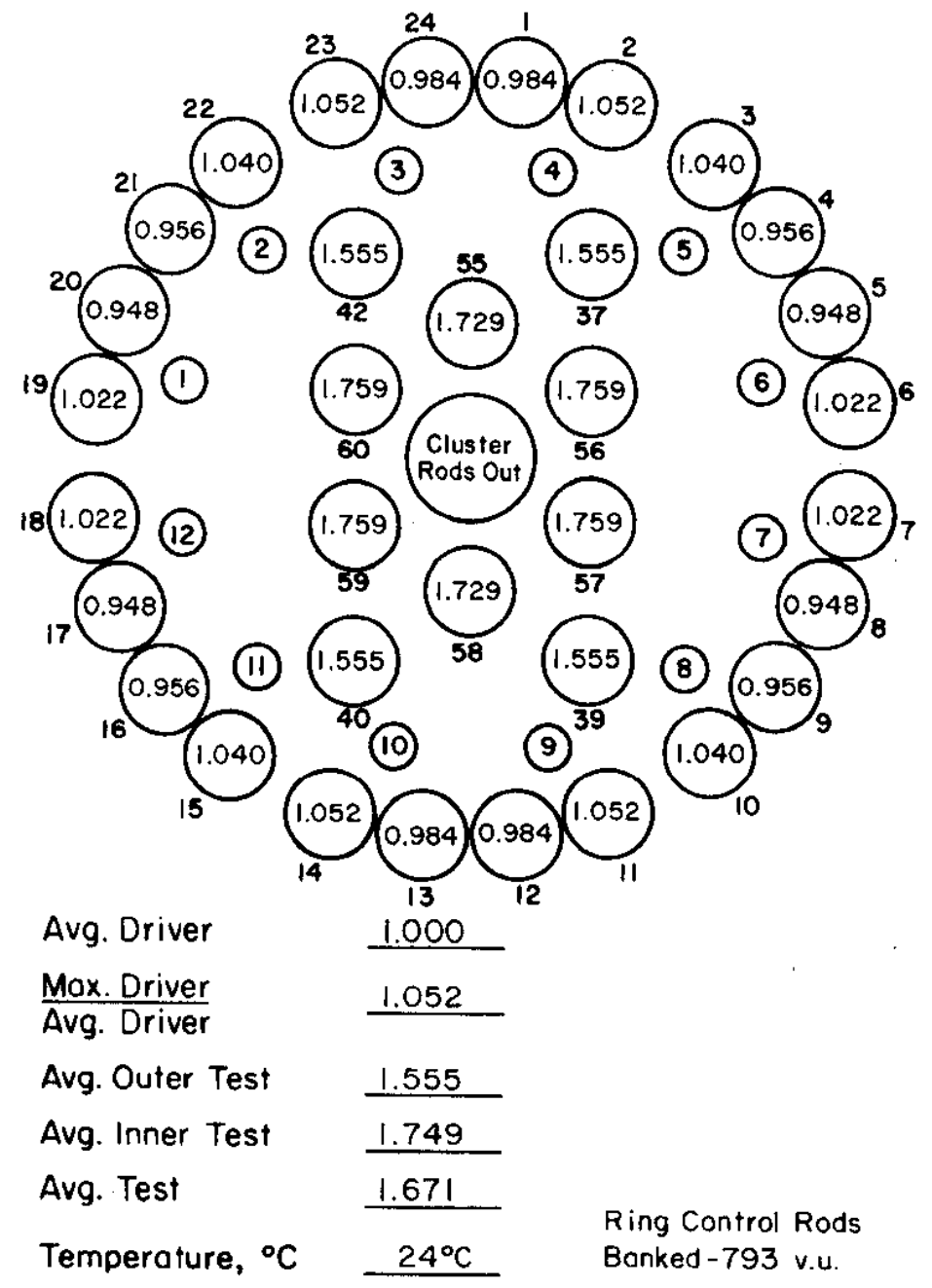

FIG. 27 CALCULATED RADIAL FLUX DISTRIBUTION 


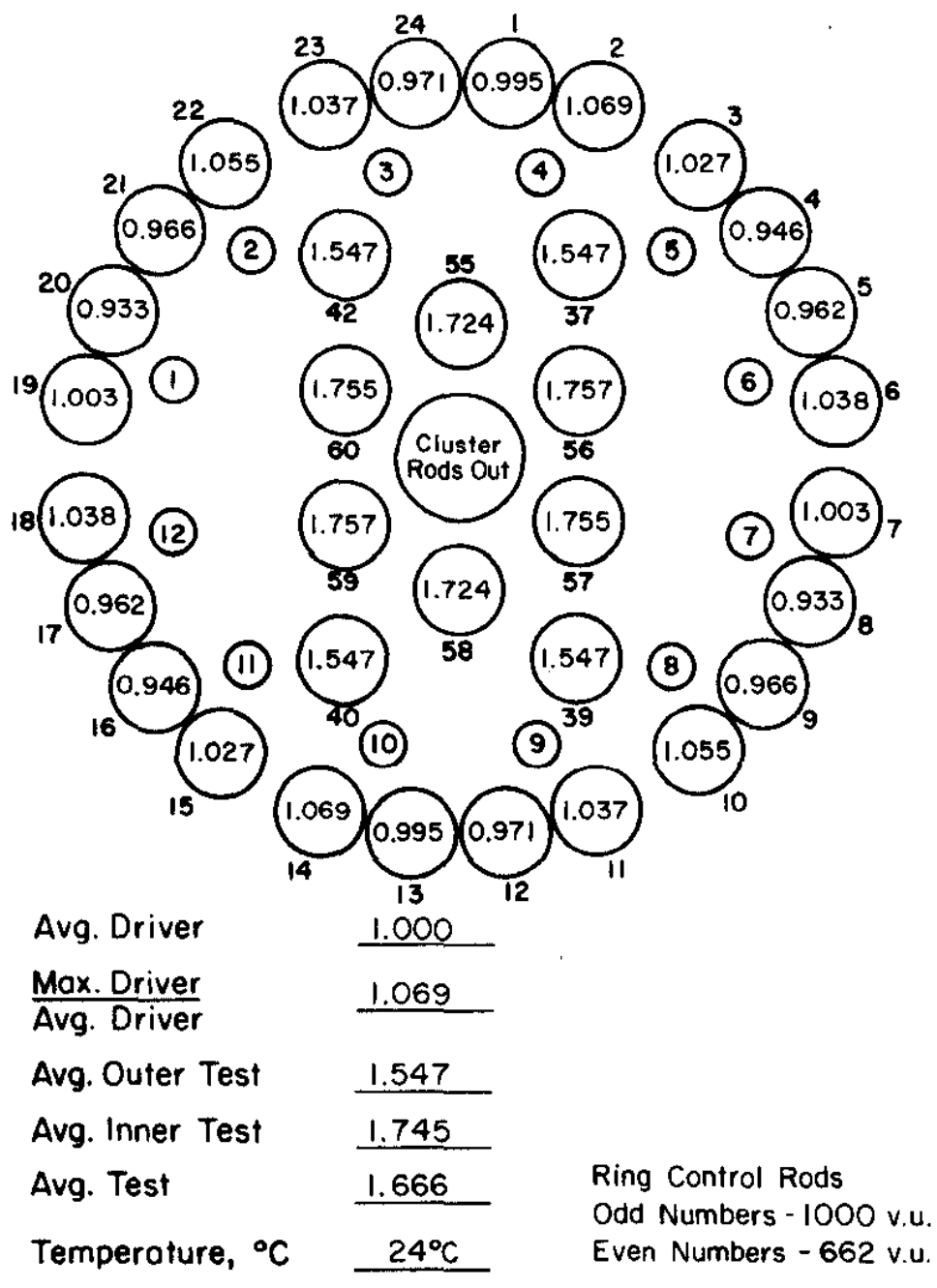

FIG. 28 CALCULATED RADIAL FLUX DISTRIBUTION 

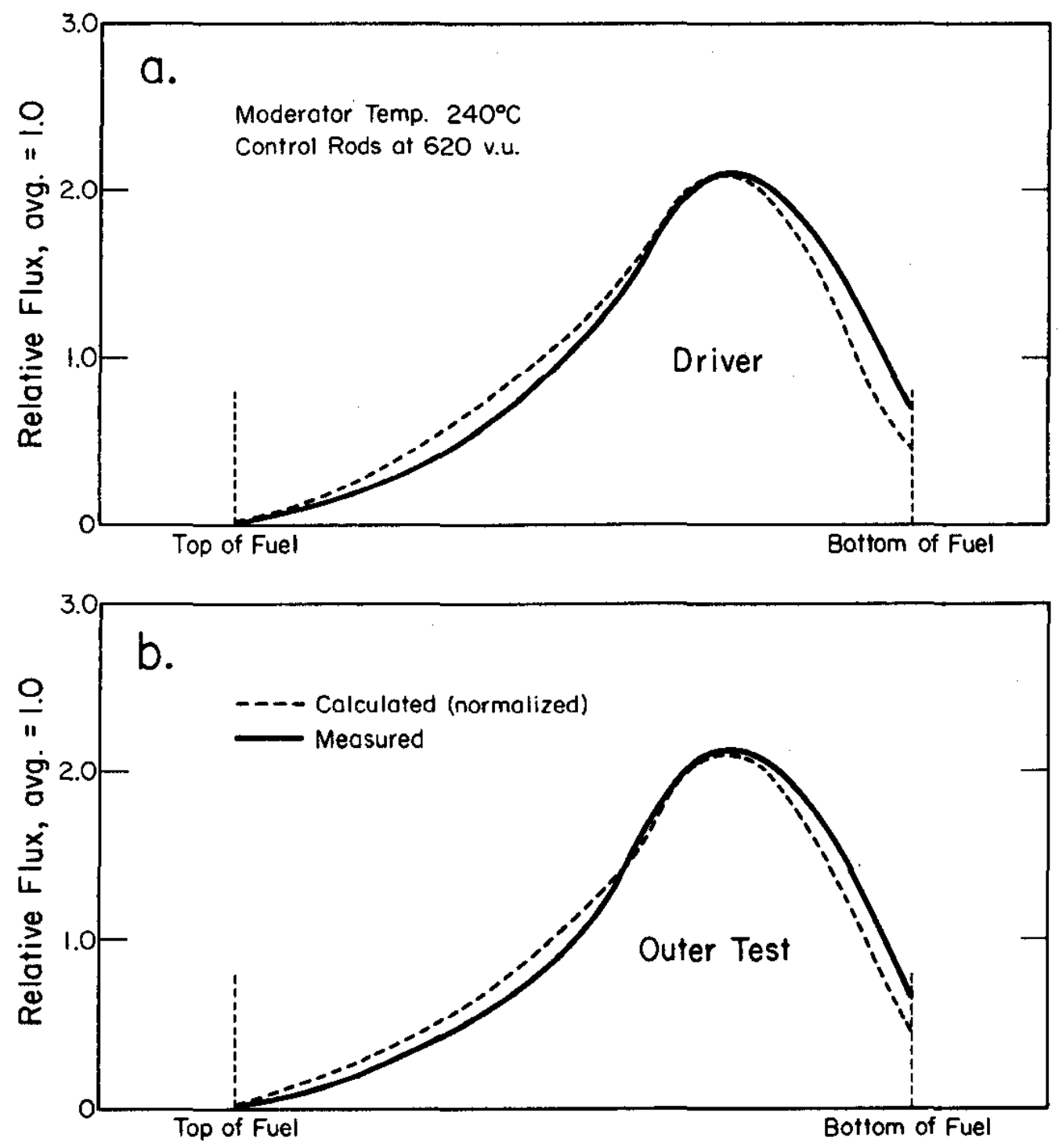

FIG. 29 MEASURED AND CALCULATED AXIAL FLUX PROFILES 


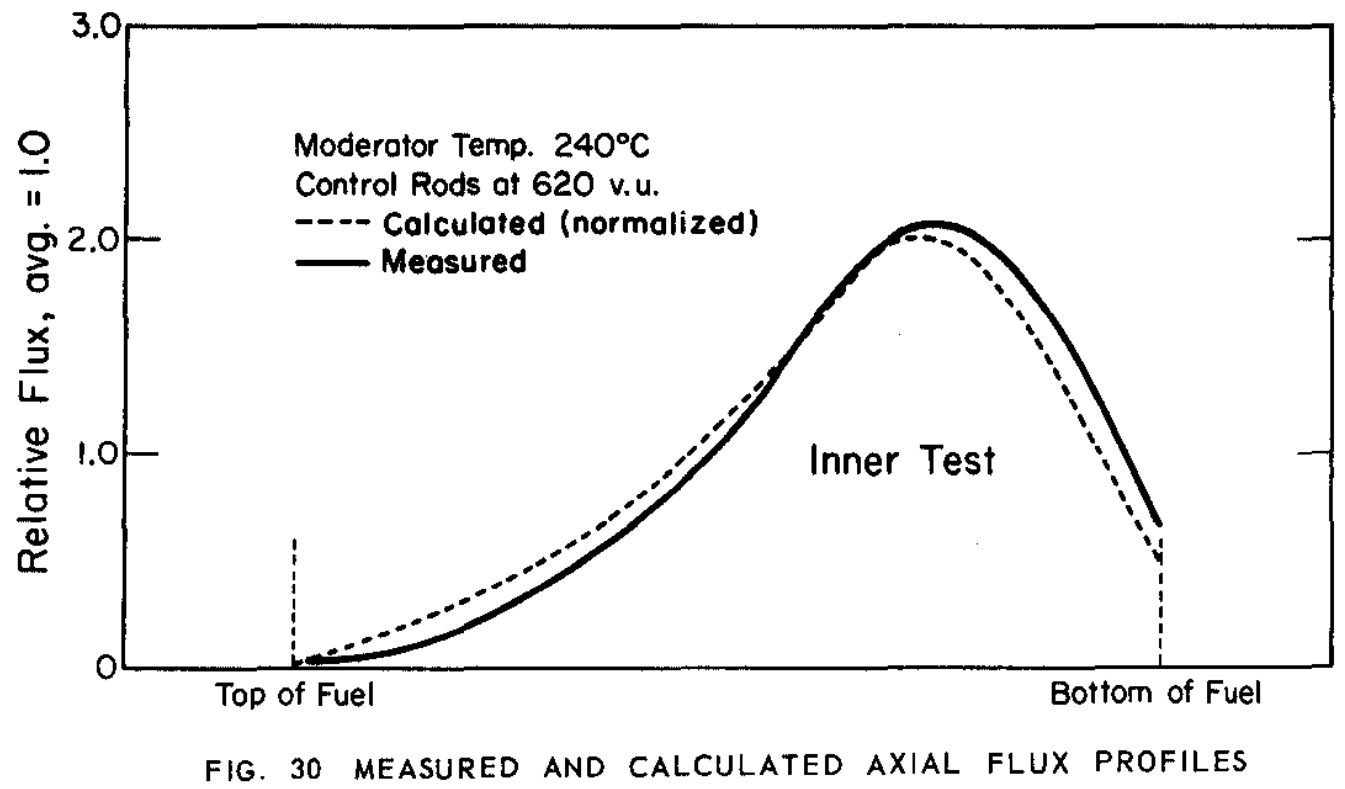




\section{BIBLIOGRAPHY}

I. I. M. Arnett, et al. Final Hazards Evaluation of the Heavy Water Components Test Reactor (HWCTR). USAEC Report DP-600, E. I. du Pont de Nemours and Co., Savannah River Laboratory, Aiken, S. C. (1962).

2. R. C. Axtmann, G. Dessauer, and T. F. Parkinson. "A Subcritical Pile for Rapid Reactivity Measurements." Chem. Eng. Progr. Symp. Ser. 52 (19) 165-71 (1956). Reactor Operational Problems II. London, Pergamon Press 173-81. (1957).

3. W. E. Graves. Physics Data from a Mockup of the HWCTR Lattice In the PDP. USAEC Report DP-457, E. I. du Pont de Nemours and Co., Savannah River Laboratory, Aiken, S. C. (1960).

4. H. P. Olson and L. M. Arnett. Control of Dissolved Gases in the HWCTR. USAEC Report DP-988, E. I. du Pont de Nemours and Co., Savannah River Laboratory, Aiken, S. C. (to be issued).

5. D. F. Babcock. Heavy-Water-Moderated Power Reactors. Progress Report for September 1959. USAEC Report DP-425, E. I. du Pont de Nemours and Co., Savannah River Laboratory, Aiken, S. C. (1959).

6. W. R. Cadwell. PDQ-3 - A Program for the Solution of the Neutron-Diffusion Equations in Two Dimensions on the IBM 704 . USAEC Report WAPD-TM-I79, Westinghouse Electric Corporation, Plttsburgh, Pennsylvania (1960).

7. G. G. Bllodeau, et al. PDQ-2 - An IBM 704 Code to Solve the TwoDimensional Few-Group Neutron-Diffusion Equations. USAEC Report WAPD-TM-70, Westinghouse Electric Corporation, Pittsburgh, Pennsylvania (1957).

8. H. Bohl, et al. MFT-4 - Fast Neutron Spectrum Code for the IBM 704. USAEC Report WAPD-TM-72, Westinghouse Electric Corporation, Pittsburgh, Pennsylvania (1957).

9. J. B. Callaghan, et al. TURBO-A Two-Dimensional Few-Group Depletion Code for the IBM 704. USAEC Report WAPD-TM-95, Westinghouse Electric Corporation, Pittsburgh, Pennsylvania (1957).

10. J. Ligou and C. Mignot. "Tridimensional Theory of Heterogeneous Reactors." Nucl. Sc1. Eng. 19, 58-73 (1964). 